\title{
GEOLOGY OF HAMILTON AND WRIGHT COUNTIES BY
}

THOMAS H. MACBRIDE 


\title{
GEOLOGY OF HAMILTON AND WRIGHT COUNTIES
}

\author{
BY THUMAS H. MACBRIDE
}

\section{CONTENTS}

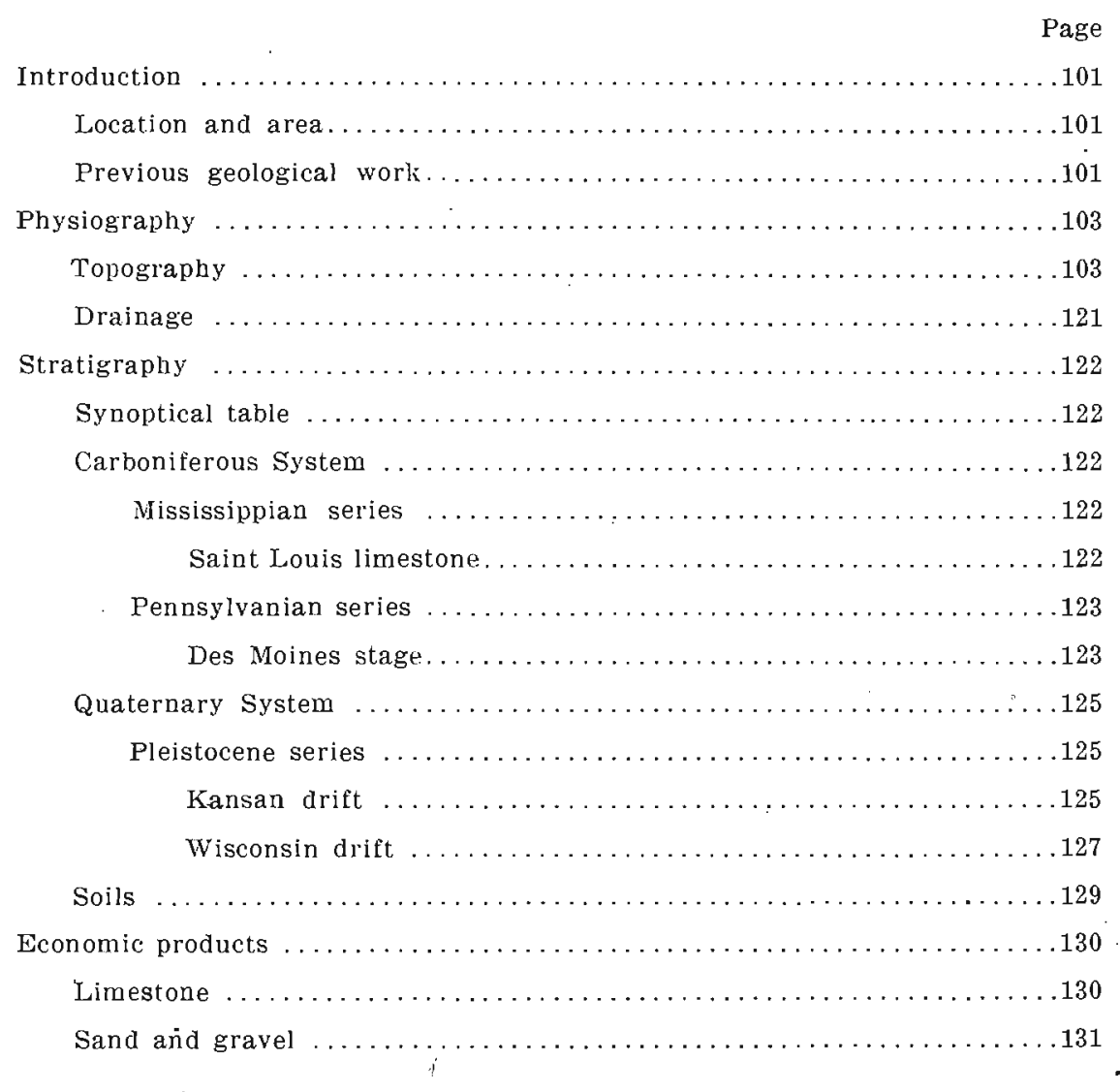


Fuel

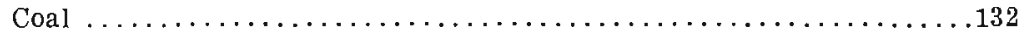

Brick and tile manufacturers ............................

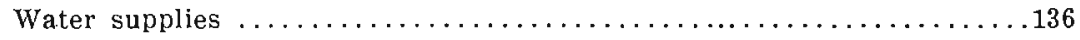

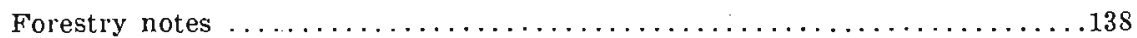




\section{GEOLOGY OF HAMILTON AND WRIGHT COUNTIES}

\section{INTRODUCTORY}

Two Iowa counties form the subject of the present memoir, Hamilton and Wright. Hamilton lies almost in the center of the state; Wright immediately nortl of Hamilton. Both are prairie counties, at first glance not unlike a score of other counties of northwestern Iowa, and yet they are not the same; Hamilton should be compared with Webster to the west, and Wright with Franklin to the east if geological affinity or continuity should determine the order of our discussion.

\section{LOCATION AND AREA.}

All the bordering territory has been already described, county by county, in these reports; Hancock ${ }^{1}$ and Humboldt ${ }^{2}$ by the present writer, Webster ${ }^{3}$ by Wilder, Boone, ${ }^{4}$ Stor ${ }^{5}$ and Hardin ${ }^{3}$ by Beyer, and Franklin by Williams. All these descriptions are made contributory to the present discussion.

Each county has its full quota of congressional townshipssixteen; and civil townships and congressional townships in general coincide. The counties are accordingly each twentyfour miles square.

\section{PREVIOUS GEOLOGICAL WORK.}

Previous to the present studies these two counties have received small attention at the hands of our natural history authors. Owen, ${ }^{s}$ in his magnificent sketch of the geology and geo-

'Iowa Geological Survey, vol. XIII, pp. 84-110.

'Ibid. Vol. IX, pp. 113-154.

Ibid. Vol. XII, pp. 63-191.

IIbld. Vol. V, pp. 175-232.

IIbid. Vol. IX, pp. 155-237.

'Ibid. Vol. X, pp. 241-306.

Irbid. Vol. XVI, pp. 453-507.

Report of a Geological Survey of Wisconsin, Iowa and Minnesota; by David Dale Owen, Philadelphia, 1852 . 
graphy of the upper Mississippi Valley passed the mouth of the Boone river in his ascent of the Des Moines. His report presents a topographic map of the greater stream as far as the mouth of Lizard creek at Ft. Dodge. On this map the terrene north and east of the mouth of the Boone is described as "beautiful prairie." The "beautiful prairie" lies about the old village of Homer in Webster township of Hamilton county. Worthen, under Hall's direction, described the counties of the northeast quarter of Towa but seems to have stopped just short of our two counties. Dr. White* visited both counties. He noted the northward extension of what is now called the Gary moraine in Wright county and in Hamilton county contented himself with a brief reference to the coal exposures along the Boone river. About $1880 \mathrm{Mr}$. Warren Upham, t studying the morainic deposits of Iowa, visited the region here discussed and mapped with more or less exactness, the trend of our principal moraines. The artesian wells of Wright county receive notice, as originating in glacial deposits, in a discussion of Towa artesian waters by $\mathrm{Mr}$. R. E. Call. $\ddagger$ Beyond these comparatively brief references, Wright and Hamitlon counties have no place in the scientific literature of the country. Of course there is reason for this seeming neglect. Counties are but artificial divisions, and are accordingly lost in topographic description where uniformity of surface and soil seems to affect the broader area. Our two counties are to ordinary travelers but a fractional part of the great "northwest prairie," and as such are simply reckoned a more or less fertile corner of a vast fertile field, part and parcel of the great maize-garden which enriches year after year the most fortunate commonwealth in the world. Nevertheless, even in the northwest prairie there are differences. It requires but a little careful attention to discover that even the surface of the country varies from township to township if not from section to section and a wider and larger survey may even reduce such variation to order and raise the suspicion, at least, that the

\footnotetext{
* Report of the Geological Survey of the State of Iowa, by Charles A. White, M. D., Des Moines.

+Ninth Annual Report of the Geol. and Nat. Hist. Surv. of Minnesota, pp. 298 et seq., Saint Peter, Minn., 1881.

¥lowa Climate and Crop Report, Vol. III, p. 5, 1893.
} 
diversity discovered is after all intelligible, proceeds in order; and follows as effect to some widely efficient cause. In this way the apparent simplicity of the prairie takes on a more than passing interest and becomes, county after county, as studied, so many pages in a volume which is at length to delight us as it makes clear to all men, at once the history of the past and the meaning of the present.

\section{PHYSIOGRAPHY}

Topography

The region we study although as a whole comparatively level is by no means the monotonous prairie that some people are wont to imagine. With a gentle slope to the south of perhaps no more than fifty feet in as many miles, there are yet distinctive topographic contrasts, level prairies and precipitous steeps, farstretching valleys, and prominent hills, besides a thousand subtle inequalities and surface variations attractive to the attentive student and as a whole lending to the ordinary observer landscape after landscape of delicate and fascinating beauty.

Topographic features generally, aside from the primeval great orogenetic wrinklings of the world, are all resultant from erosion. That is, generally speaking, the inequalities of surface with which all men are familiar are due to the transporting power of moving waters, storm-water principally, which in form of more or less continuous streams erodes and carries away vast masses of the seemingly solid ground. All our creek and river valleys, nearly, offer familiar illustration. Such topography the prairie before us exhibits; but strange to say, not well. The case is all the more interesting for this reason. Even the Boone river, the largest stream in the two counties, has no typical valley. Its waters are almost limited to a channel: $i$. e., the valley is yet comparatively very narrow; nowhere more than three-fourths of a mile, often much less, as at Webster City. It lacks the pinnate branching of a real river valley and has in fact almost no tributary streams. This, I say, makes the erosional topography in, say Hamilton county, peculiar. All things considered, the Boone river occupies a great ditch rather than a typical river valley, and when at length, near the southeast corner of the county, it empties into the Des Moines, its waters enter another 
deep but narrow ditch just like that in which they liave been streaming. Let anyone stand on the east bank of the Boone a mile or so north of old Hooks Point and look west in to the valley of the Des Moines and he will appreciate erosional topography as exhibited in all this portion of the northwest.

Such erosion is new, new as goes geologic time, new, in fact in its result, unfinished, incomplete. The banks of the Boone at the point just referred to, are perhaps one luundred and fifty feet high, and so steep as to be in places altogether perpendicular. The soft earth and clay of which the bank is made would have fallen long ago, save for two reasons: first and chief, the drainage of the country here, as in many another place, is back away from the river! and, second, the banks of our Iowa streams are wooded and small trees and bushes here in a score of species, the juniper and red cedar among them, hold fast the soil in very steep declivities, where the rain alone affords erosive energy.

The banks of the Boone, then, from Webster City south afford many of these peculiar precipitous bluffs, erosional wlolly, and maintained in their steepness by the river which slowly cuts away the base in any case, and so prevents accumulating talus. These high, steep walls afford often charming landscape views. Thus from the farm of F. D. Carson in section 5 of Webster City township one may obtain a beautiful prospect of the Boone valley and study the entire progress of the river's simple history. The river is slowly cutting away its eastern bluffs, piling the debris to the west where the valley is now three-quarters of a mile in widtll. Sometimes, thouglı rarely, the incoming of a tributary checks erosion long established, and sets the stream back to work over again its own deposits. An illustration may be seen just north of the Northwestern railway bridge below Webster City, where the Boone has abandoned the eastern bank and is now cutting west across its own flood plain.

Similar erosional topography, but on a minor scale, may be noted along the Skunk river in southeastern Hamilton county.

In an older topography where the soils to be eroded are loose or at least not indurated rock, the effects of erosion are at length very different in appearance, as may be noted by anyone who 
(V01.20) 


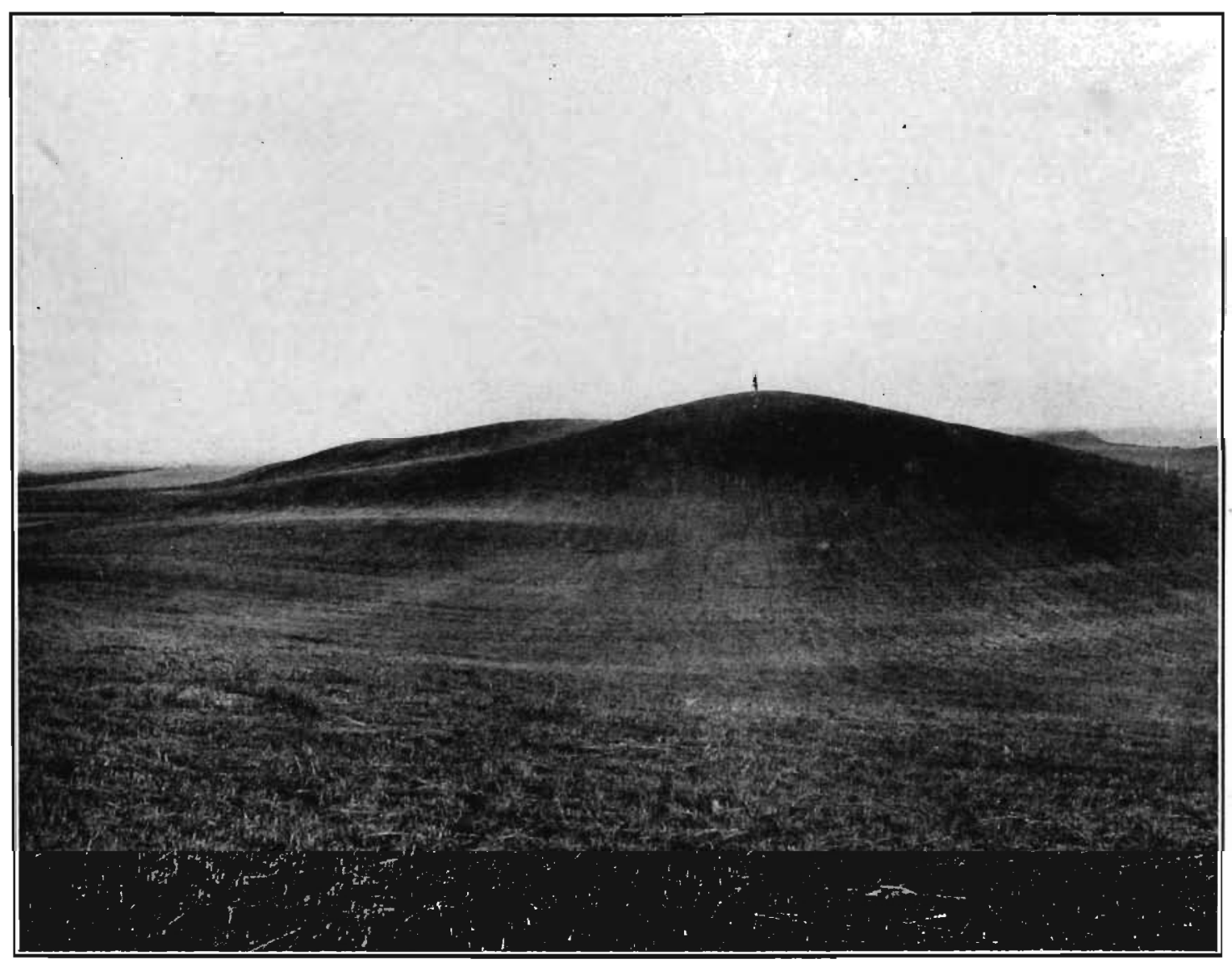

Plate XII. A mound in the meadow, Ellsworth farm, Wright county. 
$+\ldots$

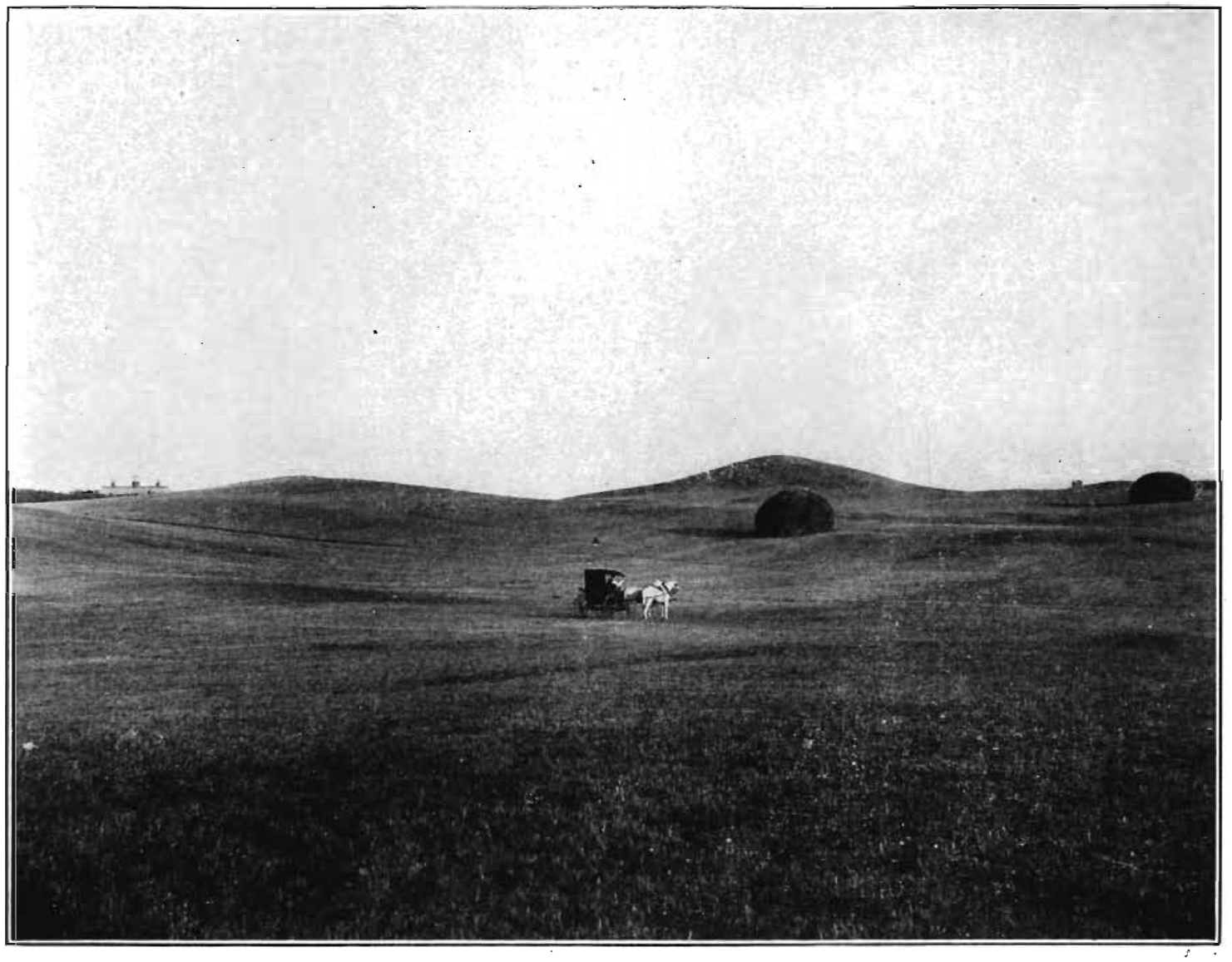

Plate XIII. Behind the moraine, looking southeast 
will compare the topography say of Crawford county where a succession of hills separated by long, sloping valleys fill the landscape.

But within the limits of these broad counties are other singular topographic features well deserving intelligent attention and discussion. The bluffs along the streams are by no means the only hills we here encounter. There are scattered here and there from north to south some of the most curious-looking hills that any student ever saw, does he but take the trouble to look at them. Sometimes a single hill, quite regular in shape stands out all by itself, far enough from any stream, on a plain entirely flat and innocent of all erosion, a hill fifty or a hundred feet high perhaps, like the mound that commemorates Waterloo, just as artificial-looking but more imposing-looking. Some there are who say the Indians strove here in savage fury, and, urged by strange infatuation, sought thus to transmit the memory of their inhumanity. But no! there are scores of such hills. Generally they are grouped together. See the beautiful cluster of such hills a mile or two northwest of Dows where the late Mr. Ellsworth built a most picturesque country-seat and every summer sent his mowers winding around these precipitous prairie mountains to cut still the wild forage from such singular grassy cones.

Once we begin to be familiar with this remarkable topographical feature of the country, once we learn well to distinguish these hills from the ordinary sculpture of erosion, illustrations start up and salute the traveler on every hand. He is surprised, for instance, if he drive south and east from Stratford to find the prairie dotted with knobs and hills, some of them sixty or seventy feet above the plain, visible for miles. One particularly in section 26 in Marion township is symmetrical and beautiful in the extreme, while in sections 15 and especially 35 and 36 are dozens less notable but all unique; at the southwest corner of 36 evidently forming the continuation of a remarkable group of such curious natural structures stretching across township after township in Boone county and away south and west, looming blue now in the summer haze, the long famous "mineral ridge," known as a landmark to the primitive red men nor less serviceable to their successors, the pioneers of sixty years ago. 
These are surely remarkable hills. No brooks or rills rise or run between them: Squaw creek flows around them, seems to shun them: only lakes and swamps or marshes lie undrained against their flanks. Clear Lake in the township of the same name is an example. The Twin Lakes of Wright county constitute another. These hills, then, are not erosional; they are constructional, since they represent the result of forces which affected the whole topography prior to the beginning of the erosion which we see now so actively in operation around us.

If we study the case a little more closely it will appear that after all there is something of system in the arrangement of these seemingly scattered mounds. The mineral ridge has been already noted, extending as it does from east to west across the northern townships of Boone county.* The ridge continues only a comparatively short distance in an east and west direction but soon divides at the eastern extremity and sends nearly north a range of hills which, entering Hamilton county near the southwest corner as we have seen, and in interrupted fashion extending far north across both counties here described, by way of Stanhope, Kamrar, Blairsburg in Hamilton county, and all the eastern half of Wright county, are especially noticeable about

- the Iowa river, which here so far drains their slopes and accompanying overflowing marshes. See Plate XIV

A second series of knobby mounds passes north from Wall Lake about Jewell in Hamilton county, trends east and north, north of Randall, and tlien north by scattered swells and knobs, coming to a culmination in curious peaks east of Iowa Lake in Rose Grove township and perhaps constituting part of the chain which becomes so conspicuous near Dows, as already noted, and leaves Wright county about three-fourths of a mile south of the line of the Great. Western Railway, say in section 1 of Blaine township.

Such hills and knolls as noted here are called morainic hills; those which fall in series and are thus traceable, more or less continuously, far across the country, counties at a time, are thought to represent the modified remnants of an ancient moraine, a glacial deposit left here at some time in the history

* See maps of Boone county in Rep. Geol. Surv. Iowa, present series, vol. V, p. 202. 


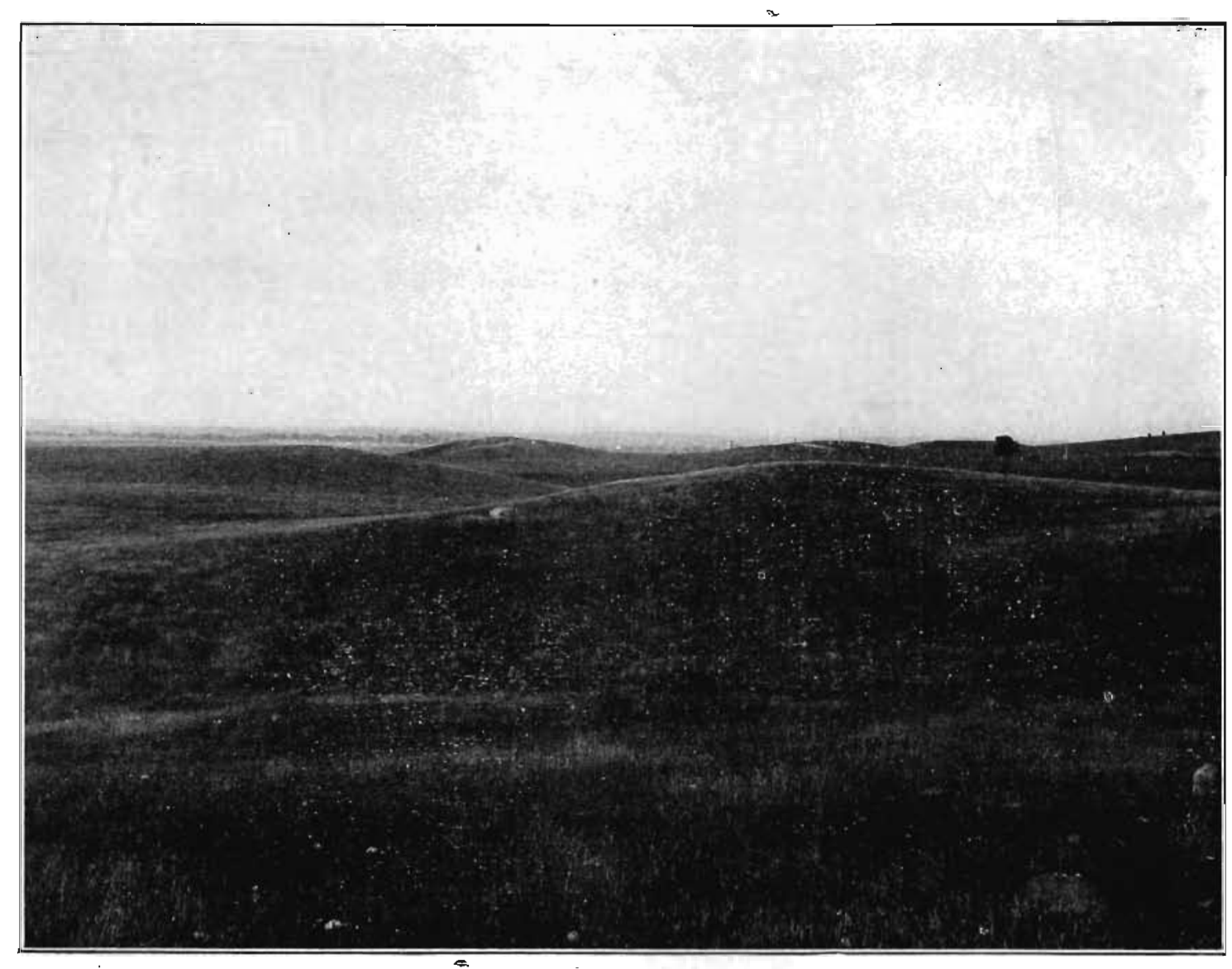

Plate XIV. Why the Iowa river runs northeast. In the moraine, looking nearly east;

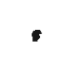
the Iowa river in the background. 
of the world, not very long gone by, when the great mass of snow and ice which still persists about the north pole of our world came very much farther south, even here to Iowa, a vast glacier pushing and spreading by its own weight along the ground, leveling the hills, filling the valleys, so long as it moved, and finally leaving these scattered piles of drift and debris where its margin rested when finally a warmer climate, by some cause ushered in, began to melt the glacier along its southern border, checked its southeast advance, shortened it, diminished it, caused it to recede ever farther and farther north until it paused at last only as a great snowcap to the planet, covering Greenland and other icy lands generally away north of the arctic circle, even as we see this day.

Wright and Hamilton counties are just inside the limits of the old glacier's furthest eastward spread or push. Traces of similar topography extend almost to Ackley along the line of the Illinois Central and almost to Hampton along the Great Western Railway, but the high hills of Dows and those about Iowa Lake are the most striking evidences of the glacier's pause, and while points near Hampton and Ackley may fix for us the very farthest reach of glacial action, the bills referred to mark perhaps a second limit when the glacier, once melted quite away, came down again, only once more to meet with check, once more dissolve away, and this time disappear for good. The moraines in these counties may be therefore termed recessional; they mark a period of wavering, of uncertainty, when the forces that have since controlled had not as yet quite attained their full dominion.

It is a notable fact that in topography such as here described, hills and lakes generally go together. The deepest and widest lakes are usually not far away from abundant hills and knobs. That is to say, the lakes of this region are morainic lakes; they owe their existence to the same conditions which have been cited in explanation of the hills. None of the lakes hereabout are very deep. They are all marsh-like, only distinguished from a thousand marshes by the courtesy of the pioneer who called them lakes to suit his fancy, recognizing their greater width and possibly, in some cases their bluffy shores. 
The lakes of the region which have thus seemed in past days worthy of a name are, with the exception of one, all nearly in a straight line from north to south. Twin Lakes, the most northern in Wright county, recently called Twin Sisters as if to distinguish from the Twin Lakes about six miles to the north, in Hancock county, are small bodies of water, beautifully situated amid fine morainic hills and knolls. These are especially developed southward and from their tops are seen rural prospects of wonderful beauty. The lakes are much visited, but are shallow; not deep enough to suppress the commoner types of aquatic vegetation so that rushes appear in islets over the entire surface. Perhaps three or four hundred acres are here submerged at the ordinary stage of water.

About three miles south over hills so precipitous that there is as yet no direct road, we encounter Cornelia Lake, which is at present nothing but a rectangular marsh covering about half a section crowded from side to side with rank aquatic vegetation. The shores are, however, sufficiently high and there is no lack of sandy beach, marked as is usual where the water of our Iowa lakes is persistent, by a distinct ice-terrace, or bench, formed by the long continued out-thrust of the ice in winter.

Immediately south of Cornelia Lake, half a mile away, is Elm Lake, a rather handsome sheet of water, deeper; surrounded by sloping hills and margined by curving, winding shores it deserves more attention than it receives. Native trees still stand along its beaches and if properly cared for and dredged a little at some points, Elm Lake might make a pleasant resort for all the people of Clarion as now for a few. The surface of the lake is a little more than a square mile, its greatest length nearly two miles.

Seven miles almost directly south of the lakelets named, is Wall Lake in a township of the same name. Here the thrust of winter's ice, acting through centuries, had gathered around the shores the bowlders originally found on the lake bottom. These discovered by the pioneer piled thus in windrows, named for him, not this lake only but one in Hamilton county, as well as a third, larger, of greater renown, already described in the report on Sac county.* Wall lake in Wright county is simply a gigantic

* See the present Series, Vol. XVI, p. 517. 


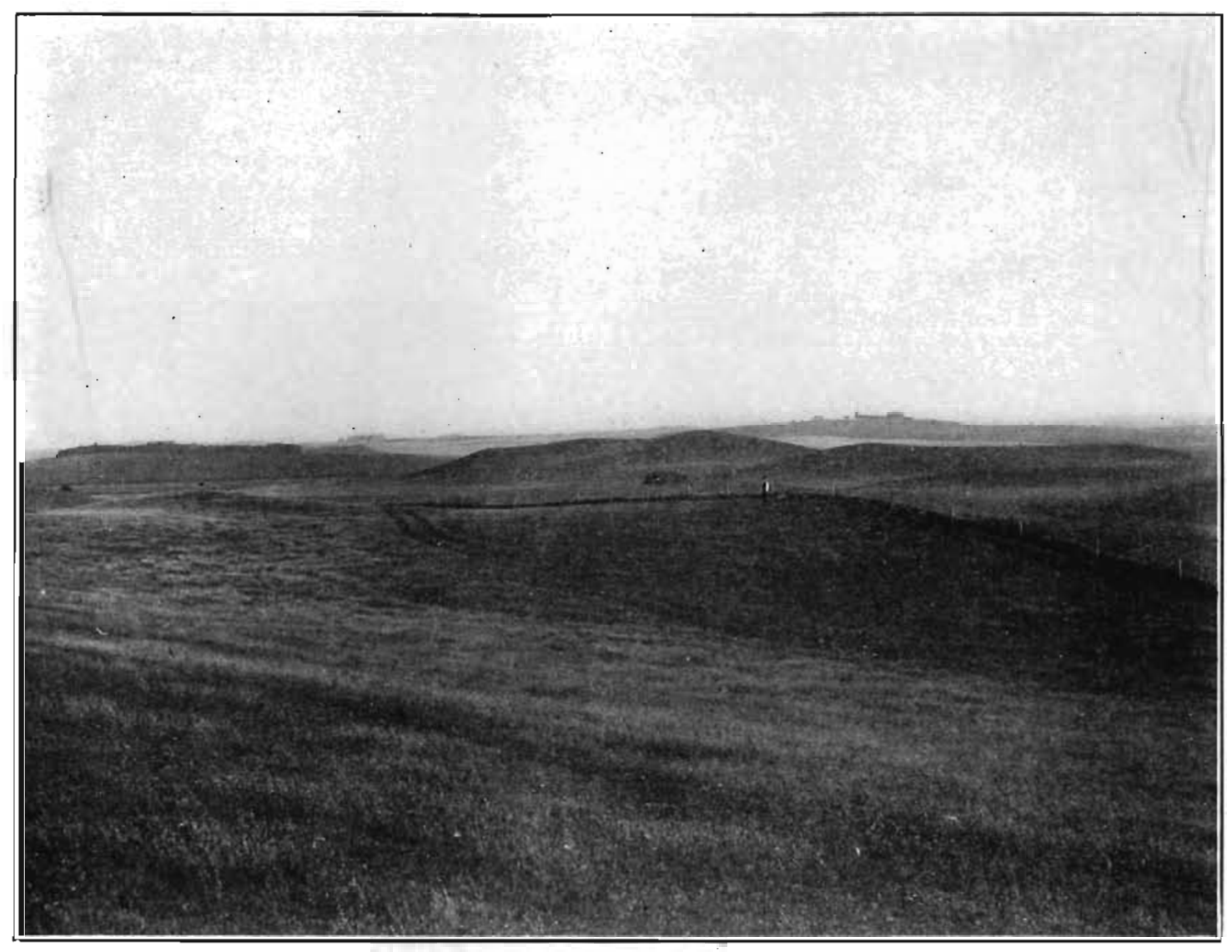

Plate XV. Such hills and knolls as noted here are called morainic hills. Part of the moraine in eastern Wright county, near Dows 
$(v .20)$ 
"kettle hole" in the midst of the plain. The morainic hills here stand somewhat aloof, a mile or two, to the east and south, and another great marsh called Wheeler creek, but with no eroded channel, lies between Wall lake and the hills. The wall of the lake seems to have long since disappeared, hauled away to make foundation stones in structures they will doubtless again survive. Only at the southern end of the lake a few bowlders appear, heaped up now to lielp the lighway that here skirts the shore. This is perhaps the largest lake in the two counties, covering more than two sections, but its shallowness makes it less attractive, and the wild rice and bullrush seem to thrive almost from side to side. Low morainic swells approach its borders on the west and afford warm, sunny slopes to many beautiful farms and groves.

In Hamilton county three lakes only have heen thought worthy of the name. Cairo Lake, almost immediately south of the Wall Lake just described, a second Wall Lake, three or four miles southeast of Cairo, and Iovia Lake on the eastern border of the county, notable as one of the sources of the Iowa river. Of these lakes, the first has been imperfectly drained by an open ditch. The lake is still marshy over a section or two of land, appears to have enjoyed a good beach along the east and a grove of native trees still extant. Iowa lake is possibly quite as large, is now in process of drainage, and if the open ditch proves successful, Iowa lake will soon be a land of corn and meadows, girt round to north and east by beautiful, typical morainic hills.

Little Wall Lake, soutl of Cairo lake three or four miles, is a picturesque little pond, lialf a mile wide and a mile or more long, nearly surrounded by steep, wall-like hills. Had it depth Little Wall lake would be the attraction of the landscape, but its shallowness makes it simply a great marsh filled from side to side with aquatic plants. The margins are dark with sedges. In the middle the cat-tail lifts its blades undisturbed, while over the deeper waters the pond lilies spread their broad leaves like inverted shields and star the surface with flower's. Innumerable birds fill the air with strident, unmusical sounds; ducks steer their miniature fleets about; mud hens wade among the calamus roots; blackbirds cry as if life depended upon unceasing noise; 
the tern hovers above the more open waters or sits upon the sand as if by sea; the bittern sits among the reeds, bill straight up, more like an inverted stake than any "stake driver"; and over all, in the evening, clouds of insects-mosquitoes make gray the air on every side. For the rest, bowlders now are few; occasionally a big one lies by the shore tumbled down by the undermining of the waves, here and there sufficient when the lake is full, to beat against the steeper shores. In the earlier morning the mists from the waters screen from the traveler the beautiful grain covered hills that slope down on every side and the lake lies in primitive wildness, an isolated reminder of the weird marshy topography that so recently characterized not these counties only, but all northwestern Iowa, the land of a thousand lakes.

But while the mounds and lakes are thus interesting features of this region, the wide, almost perfectly even plains on which these are displayed are none the less. The prairies of northwestern Iowa where not ocenjied by marsh or morainic knob are as a whole the still mweathered, uneroded floor over which the morthern glacier noved; not absolutely level, of course, but often surprisingly near it. The general slope is south and west. Thus on the west side of the territory here described we have Thrall, altitnde, 1144 feet; Highview, 1137; Stanhope, 1122. Going down the east line, we have Meservey, 1255; Alexander, 1253; Williams, 1212; Radcliffe, 1194. The prairies about Highview, an almost absolute plain! afford an illustration of this singular featureless topography. The whole landscape is at once in vision; diminishing louses, groves, villages disappear on the horizon, lost by distance only.

A terrene such as that just described is, of course, much lacking in drainage of the ordinary sort. The traveler today is amazed to see dredge boats steaming about athwart the meadows following the imperceptible slope of the prairie as by the construction of wide canals they furnish the necessary conduits for the conveyance of surface waters. Under such circumstances it would appear that little is to be said upon the general topic of- 


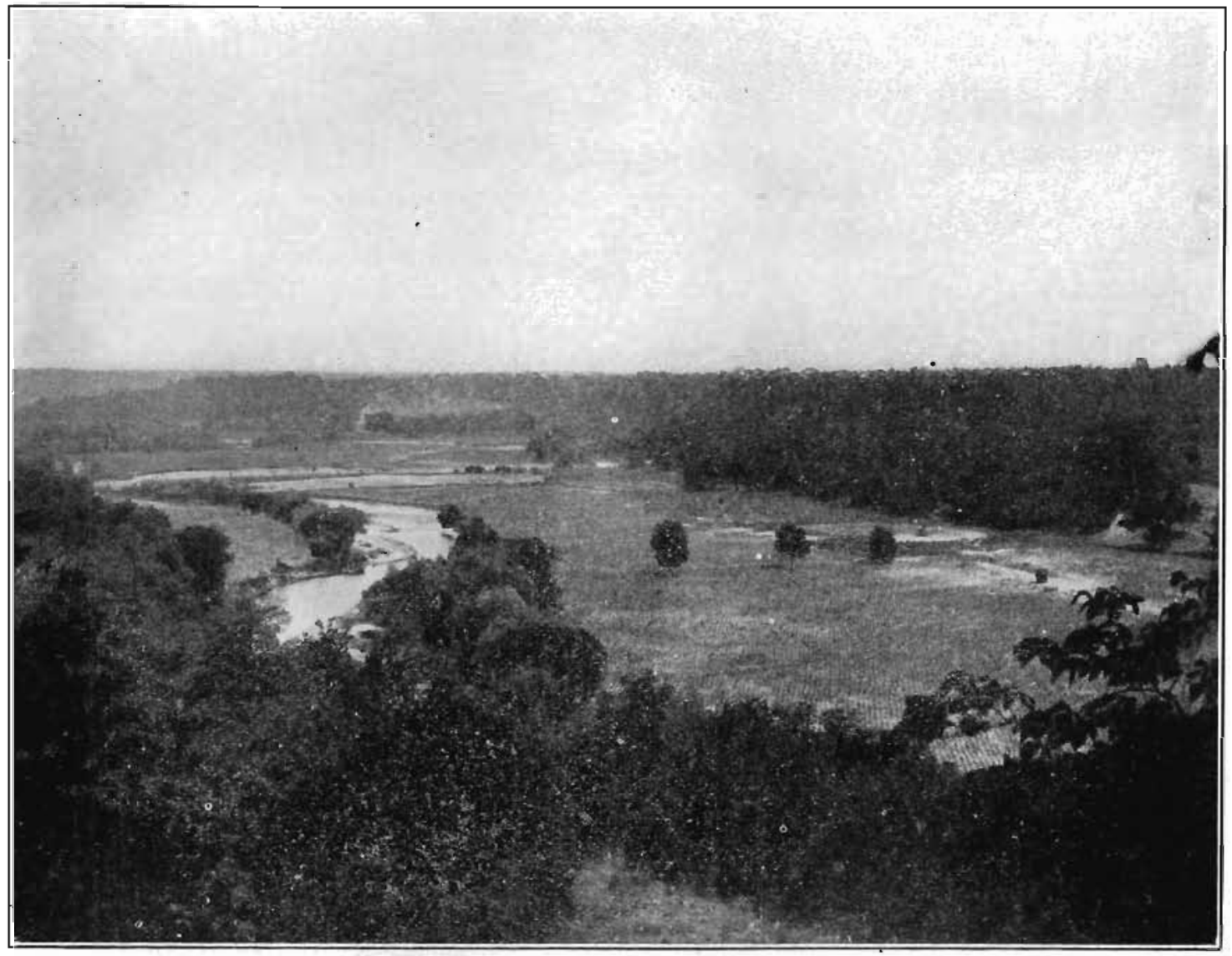

Plate XVI. Where the Roone winds across its flood-plain before entering the Des Moines valley just visible in the extreme left of the picture. 


\section{Drainage}

The Boone river, which traverses almost entirely both these counties from north to south across their western townships, affords excellent drainage so far as it is developed. We are here near the mouth of the river which enters the deeply eroded Des Moines in Webster county not far from the southwest corner of Hamilton. The Boone accordingly shows for some distance up stream a channel almost as deep as that of the larger river; its banks are sometimes one hundred to one hundred and fifty feet high. Accordingly, lands immediately contiguous are generally well drained. However, such is the peculiar topography of this country that sometimes the drainage of the highland is actually away from the river, so that all this deeply eroded channel of the river avails but little. See Plate xvi

Several tributaries of the Boone are more or less serviceable to the drainage of Wright county. Otter creek, Eagle creek, and White Fox creek, all flow soutl in the western part of the county and in many places afford outlet for tile draining. White Fox is an eroding stream and farms adjoining it are well drained. The same thing may be said of Eagle creek, but in both cases the service is limited almost to the cliannel of the stream itself. There is no valley and there are few tributaries.

The soutl townships of Hamilton county are, for a Wisconsin drift region, well drained. Here we have the sources and head streams of the Skmk river. Squaw creek and the forks of the Skunk are erosive water's and drain a beautiful country. Long. Dick creek is a typical prairie slough extending north and south through three or four townships but leaving the adjoining lands practically unaffected.

However, as ảbove suggested, great open ditches are now everywhere in course of construction to help out these prairie water courses. It is possible that the unlimited tiling brought from the fields, from every direction, may afford sufficient perennial water to keep in the main ditch a constant stream strong enough to maintain the channel thus artificially offered. 


\section{STRATIGRAPHY}

The indurated rocks of the older horizons are in these counties generally buried far out of sight and reach by the field of drift. We know of their presence in most places only on the testimony. of the well-digger. However, as will appear, the Boone river has in its lower course cut through the entire drift series and reveals with more or less clearness the formations immediately below.

SYNOPTICAL TABLE

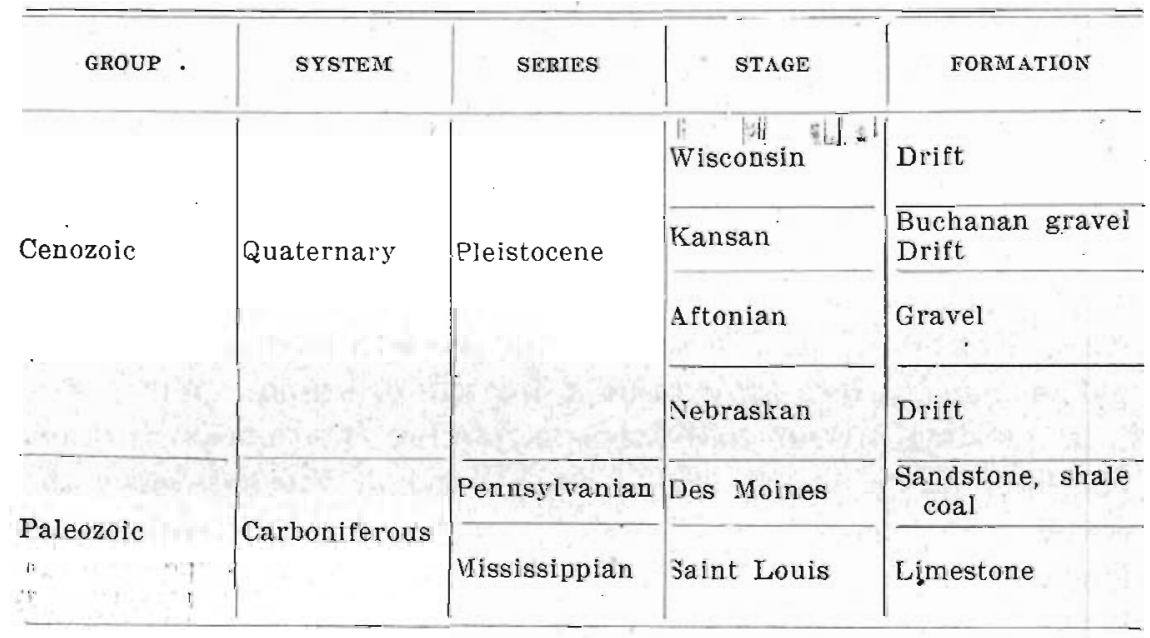

\section{CARBONIFEROUS SYSTEM}

\section{Mississippian Series}

SAINT LOUIS LIMESTONE.

In several places south of Webster City the Boone river has cut down through all drift and exposes the stratified rock of the country. Thus quarries along the Brewers creek near where it enters the Boone show the section following:

6. Alluvial soil and

6. Alluvial soil and gravel......................... 3

5. Weathered ferruginous gravel...................

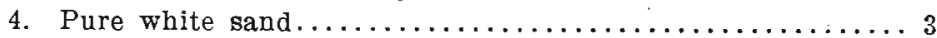

3. Laminated sandy shale............................ 4

2. Hard crystalline limestone...................... 5

1. Irregularly bedded and cracked limestone down to water level ...................................10 
A few rods farther west of the section thus diagrammatically shown, a drift section also appears above the indurated rocks:

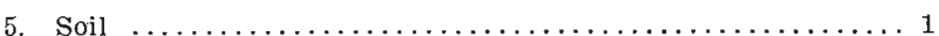

4. Wisconsin drift, sandy, with abundant sand bowlders...12

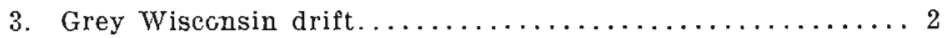

2. Sand, white, grey, some ferruginous................ 3

1. Irrégularly bedded limestones..................... 8

Number 1 in each section is referred to the St. Louis stage of the Mississippian; on lithological characters chiefly; but the position in the series suggests the same reference, the sand and sandstone above representing the Pennsylvanian. Lithologically the rock in question resembles that occurring in Humboldt county in and about the town of Humboldt and discussed at some length in volume nine of the present series, page 127 et seq. Beyer seems to have encountered similar beds in the northwest part of Varsliall comnty, along the Skmok river in Story, and refers all these exposures to the St. Louis.*

\section{Pennsylvanian Series}

DES MOINES SANDSTONES AND SHALES.

The Pennsylvanian exposures are limited to the banks of the Boone river and its tributaries soutl of Webster City. There are many such; and coal for many years has been successfully mined at intervals all the way from Silver creek to the mouth of the river. While the mining lias been extensive, of late the industry appears to have almost entirely lapsed, and there are at present not only no good exposures of the coal-seams and accompanying strata, but no mines were found in operation. Exposures occur where the river at flood undermines some portion of the unstable bank and produces a land-slide from above. Such slides liave taken place at several points where mining had helped on the effect of basal erosion. The result is sometimes a good section of the upper drift sleets and complete sepulture of everything below. Such has been the history of the case in section 19 of Webster township, a short distance east of the tunnel.

However, by the aid of miners and others a tentative section may be studied at the mouth of Silver creek in section 36 of

* See of the nresent serjes Vol. VIT, n. 227. 
Freedom township. Here is a mixed exposure of something more than one hundred feet to be distributed somewhat as follows:

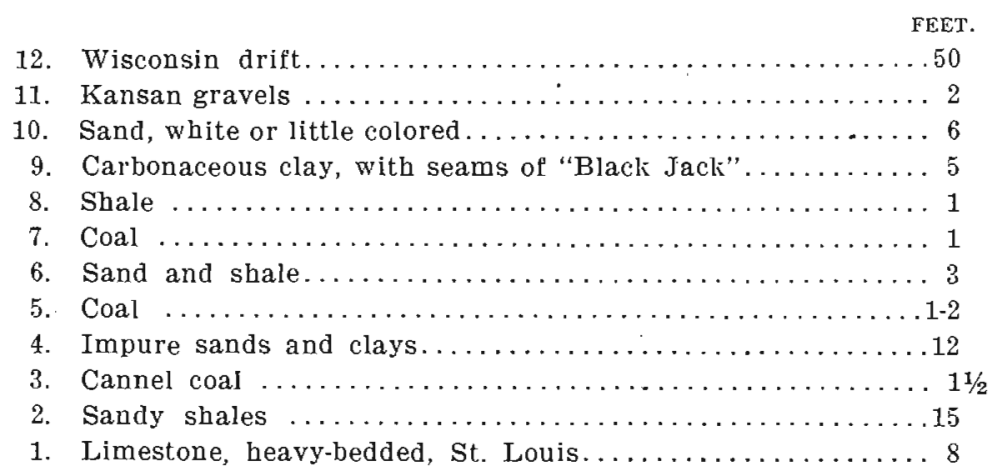

This table shows the relative situation of successive horizons; the thickness in eacl case cited must be esteemed an estimate. Number 7 was well exposed and at the point observed does not exceed one foot in thickness. Number 5 was reported from twelve to twenty-four inches of good quality. The cannel coal lies some ten or twelve feet below number 5 and is reported twenty to thirty inches in thickness. On the east side of the river nearly opposite the mouth of Silver creek, erosion had removed everything above number $t$ and a large part of this, so that the pioneer farmers by only light stripping done with the plow and scraper, obtained considerable supplies of what is called cannel coal, which seems to be entirely satisfactory for many domestic purposes.

The limestone at the river-edge appears to be the same as that exposed farther up stream and is referred to the St. Louis. It seems to dip out of sight up stream and is replaced in the bed of the river by a heavy-bedded sandstone which has been to some, extent quarried.

Carboniferous sands and shales with seams of coal have been exposed by the river for many miles along its winding course, but such exposures are at present in almost every place covered either by sliding drift or, in the river bed itself, by bowlders and beds of gravel and sand. Coal has been taken from such eroded banks in several places as in section 13 , section 21 , section 30, Webster township. There is an apparent outcrop of 
coal in the bed of the river in section 30, almost directly north of Stratford, but this probably is not in place; the seam appears to be on edge and is likely a shear from the adjacent bank, here very steep.

In general, the Paleozoic rocks along the river are covered, even where exposure is to be expected, by recent slides of the overlying drift. This is particularly the case where coal mining has been in progress.

\section{QUATERNARY SYSTEM \\ Pleistocene Series}

KANSAN DRIFT

Exposures of the older drift are rare. There are, however, some sufficiently fresh to be legible. Those at the Webster City quarry and at the mouth of Silver creek have been already mentioned. As one descends toward the Boone from the north, in Webster township the contact of the older and later drifts may be sought. On the north side of a bridge crossing a small stream in the northeast quarter of 19, Webster township, occurs a peculiar exposure of what is probably Wisconsin, showing the curious gray drift, previously mentioned in these reports, capped by beds representing perhaps sand-bowlders, or some particular local condition at the time the drift was laid down. There are beds of sand and ferruginous gravel, evidently related to the ferruginous sands of the Carboniferous strata in the neighborhood. Possibly the gray Wisconsin represents simply that part of the deposit which contains an admixture from the coal seams, black and gray beds of material over which the glacier passed and which it may have found not covered by older drift, in this immediate vicinity. A piece of coal weighing a few ounces was found in the gray material in the exposure here described. This material lias not traveled very far; it is local.

But farther south, the road cuttings, where that highway goes down to the bridge, show the older drift in several places, although, owing to continual wash from above, the contact was not well made out. On the north side of the river the Wisconsin deposits are about fifty or sixty feet in thickness; on the south side of the stream, in the roadway only the older drift appears, 
at least for a considerable distance up the hill; at the summit, the characteristic light-colored Wisconsin may be traced again and morainic swells show how the course of the Boone was long ago deflected west.

But although on these level, uneroded prairies the older drift is now generally invisible to the traveler, its presence everywhere beneath the surface is none the less exactly ascertained. The "blue clay" is a matter of universal testimony. Its tough unyielding consistence, its relation to underlying aquiferous sand or gravel, nor less the multitudinous inconvenient bowlders imbedded in its impervious mass, make the formation familiar to every well-digger, almost to every farmer. The blue clay is everywhere in Iowa recognized as representing the Kansan drift; and so in these counties, although the Kansan in its several members may not be seen and studied often at the surface, nevertheless it may be assumed as covering the indurated rocks or Carboniferous shales and clays over practically the entire area.

The thickness of the blue clay is a matter of practical interest but of record incomplete. Those who drill through it find it variable; nevertheless in these two counties no reports quote so much as two hundred feet; the usual statement is "fifty to one hundred and fifty" feet. This will be discussed onore fully under the head of water supply later on. It is understood that the blue clay here referred to represents only so muclı of Kansan clay as has not yet suffered oxidation: Where the clay has long been exposed to the weatlier, it becomes yellow or brown as seen in the road-sections, already referred to, near the Boone. In fact as just stated this particular member of the Pleistocene deposits of Towa may not be well studied in such locality as is now considered, simply because not well exposed. But we may not ignore a formation so widely and definitely recognized. It would be to science of the highest interest and to the community of no small practical value did every contractor who constructs a well on the Iowa prairies keep an accurate record of the course of his work. Were such records kept we should presently be in possession of a mass of facts relative to the structure of our soils and the surface and water sources of Iowa such as may be had so easily and speedily in no other way. 


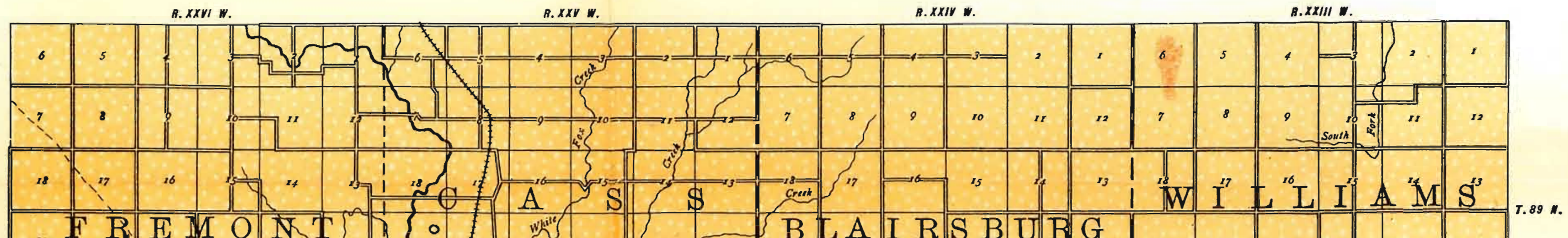

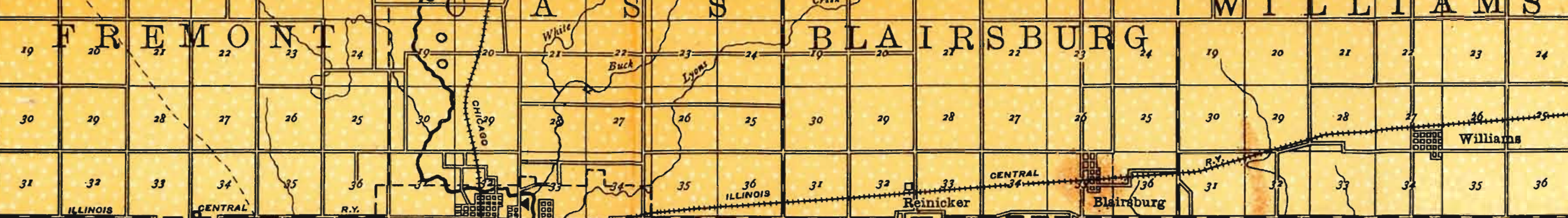

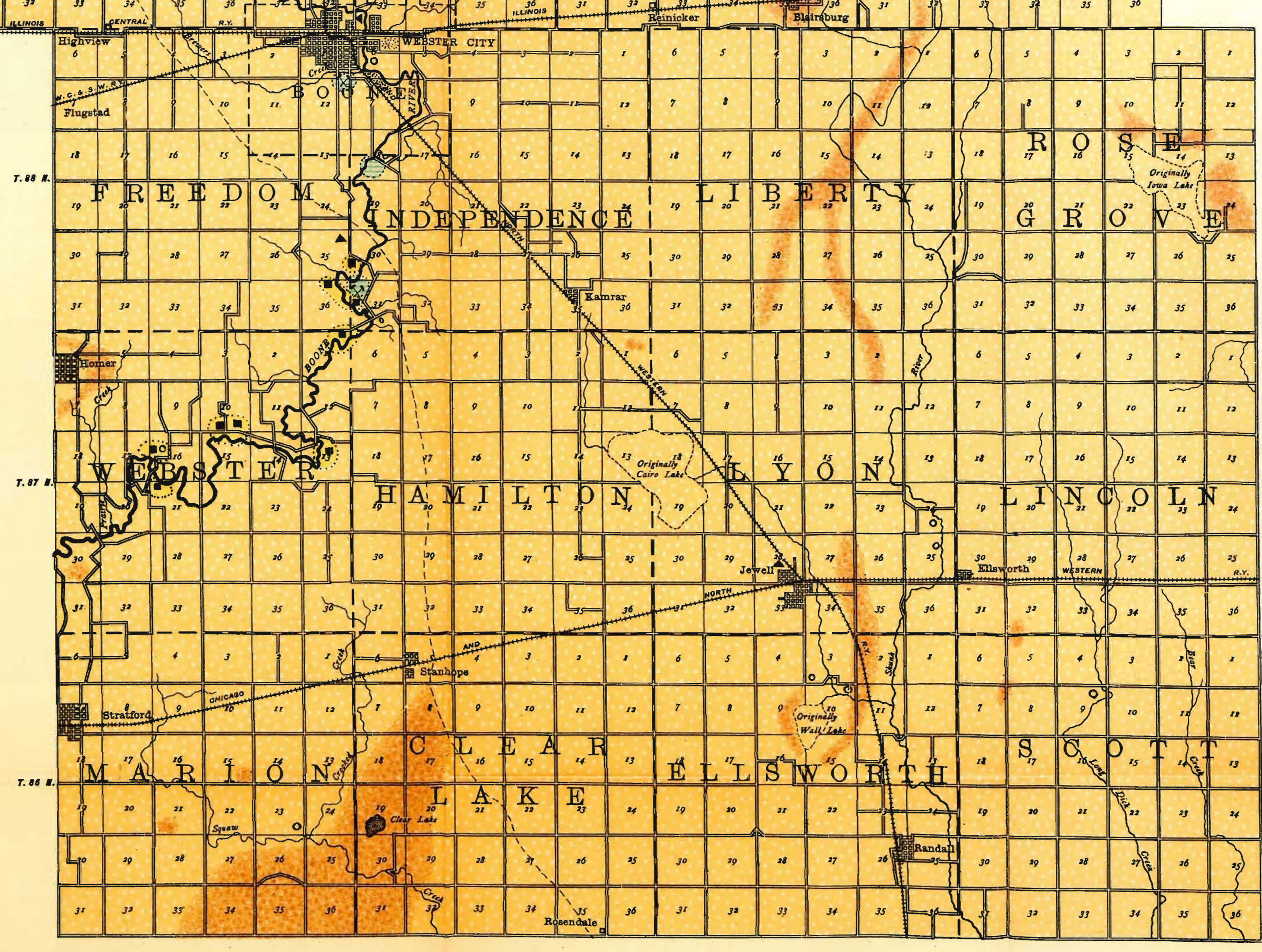

IOWA GEOLOGICAL SURVEY

MAP OF THE

SURFA

RFACE DEPOSITS

TANDOCTON

COUNTY,

IOWA.

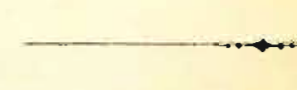

BY

T. II. MACBRIDE

1910

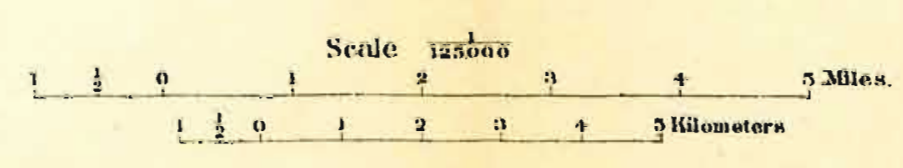

I. EG E N D

GEOLOGICAL FORMATIONS

WISCONSIN DRIFT

WISCONSIN MORAINE

PENMSYLYNANAN

MISSISSIPPAN

$\square$

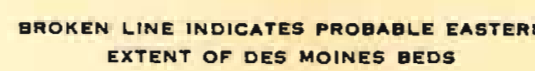

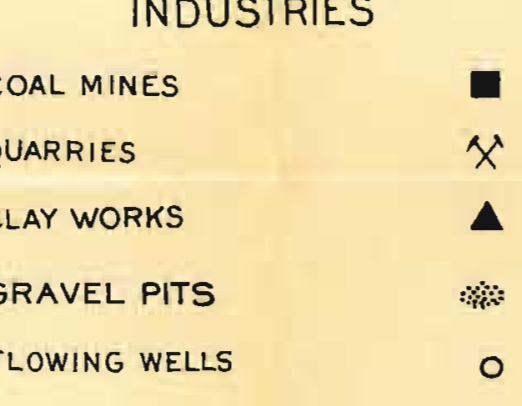


In the counties of Carroll, Boone and Hamilton, there is a little difficulty in making sure of the identity of the blue clay in some localities, owing to the fact that in some places the lower Wisconsin may be taken for it. However, the gray Wisconsin is after all, once comparison is made, not blue clay; it is much less compact, of different color, much darker, especially where dry, and disintegrates much more easily and readily, lacks the peculiar slippery or soapy feel, which will be recognized by everyone who has had his hands on this peculiar deposit. But this we may better discuss under a new topic-

\section{WISCONSIN DRIFT}

This name is now applied to the upper drift or pebble-clay covering all central and northern Iowa. In the two counties here described it forms the almost universal, subsoil. It is exposed by the erosion of streams, and may be seen in "claybanks" fifty or sixty feet high along the Boone where the undermining waters have caused the sliding of acres at a time, as in section 13 in Webster township, Hamilton county; it is exposed along all railways, as along the Great Western in Wright county; it may be seen on nearly every highway where a cutting of a few feet discloses the peculiar whitish or pale yellowish, calcareous pebble-clay. Tile ditchers toss it up in every field. The formation includes also the great piles of drift, beds of gravel and sand, making up the mounds and hills already described as characteristic features of the topography here. These hills are used coinmonly as sources of supplies for sand and gravel; but many times they consist simply of the same materials that constitute the more level grounds; they are drift, a mixture of fine yellowish clay-like material with abounding bowlders and pebbles of every dimension; in the present case the pebbles are largely calcareous and white. Under the influence of the weather the Wisconsin drift loses its pebbles in large measure; consisting of lime, they rapidly decay and we have left a fine clay-like soil, exceedingly sticky when wet, immensely productive of vegetation, and now black, with the accumulated organic stuff of many centuries.

Although the Wisconsin drift in these counties reaches in some places considerable thickness, as in localities where it 
seems to fill depressions in an older topography, or where it is evidently piled in hills and mounds, nevertheless the deposit as a whole seems relatively thin. Open ditches, ten to fifteen feet in depth, are commonly constructed on all the more level prairies, for the purpose of more effectively draining the abundant marshes. In constructing these ditches the shovel not infrequently encounters blue clay. This would indicate that in such places all the weathered Kansan had been pushed off or eroded in advance of the Wisconsin ice, and means, of course, a very thin deposit of the later drift. The average thickness of the Wisconsin drift in the counties here studied would not seem to exceed fifty feet.

Mention has been made of a dark colored or gray Wisconsin deposit. This has been observed in not a few localities hereabout. (See Vol. XII of the present series, pp. 133-135, where also Illinois reports are cited.) The present writer has observed difference in color in the Wisconsin deposits in the northwestern part of Carroll county, in Webster county a few miles south of Ft. Dodge, along the Des Moines river, in cuttings along the Newton and Northwestern Railway northwest from Boone, in the quarries and railway cut southeast of Webster City as noted in section for St. Louis limestone, p. 122, and in the section already mentioned south of Homer in Hamilton county. But the finest drift exposure seen in these two counties occurs in the very northwest corner of the town of Webster City. Here the river has undermined, for years has been undermining, the bank on the southern side. The result is a "clay bank," a bed of drift, seventy-five or a hundred feet high, extending perhaps half a mile along the river. A section of the drift here shows:

3. Black soil, about........................... 3

2. Yellcw Wisconsin, impure.......................

1. Gray Wisconsin with fragments of shale and coal........70

Inasmuch as the erosion seems to proceed steadily at the base of the bluff so that the face is kept nearly perpendicular, it seems probable that the blue clay here forms the bottom of the river; if so, the face of the bluff represents the total thickness and the character of the Wiseonsin drift at this particular point. The dark colored drift here is almost of the same color as some of the 
Carboniferous shales of the neighborhood, and fragments of such shales still persist as a common element in the make-up of the deposit. Fragments of coal are also not unusual. The gray drift is liard, compacted, rather inclined to a crystalline, splintery cleavage; not tough like the blue clay. It has been suggested that this variation in color is due to difference in age. Data are not yet at hand in number sufficient to warrant much inference; but so far as observed there is nothing in the sections noted to indicate any time factor whatever. The two colors wherever shown pass over into each other almost without a break.

It seems more and more evident that the local beds and peculiar local ingredients and not lack of oxidation must be responsible for the peculiar color. This supposition is not inconsistent with the relative position of the two members where seen in section. The yellow upper portion represents a burden brought in the upper ice and from far; the dark colored stuff was in process of accumulation when the movement ceased. These deposits, so far as reported are all marginal. At any rate there is nothing so far observed to indicate interrupted deposition.

\section{Solls}

The soils of Hamilton and Wright counties are nearly all of one sort, prairie of the blackest and richest. There are some alluvial benches along the course of the Boone in both counties, and along the Skunk river in the southeastern townships of Hamilton county, but these are not continuous and are of limited area. In the vicinity of the norainic hills the soils are lighter, conspicuously so in some places, as in the western part of Scott township, Hamilton county, and in the northeastern part of Rose Grove township; but in general we have a calcareous soil full of accumulated wealth of years unknown and long gone by, a soil that requires skillful tillage only, to become a garden to the satisfaction and service of men. The only hindrance so far has been the imperfect drainage, characteristic of all north central Iowa. This defect, however, is now in course of rapid correction. Great public ditches stretch from marsle to marsh 
and pass straight down the low valleys of natural drainage, offering to the adjoining farms outlet for tiles, which will soon in perfect network reacli every undrained field.

Along the larger streams, notably along the Boone, the steep banks show exposures of unweathered drift. These were originally, and are largely still covered with native forest. Such localities should be preserved as woodland, to furnish a local supply of building materials and wood for fuel, fencing, etc. These steep banks cannot be cultivated; they are often too steep; in any case, once the timber is cut off, erosion cuts the whole hillside into gullies or causes it to slide bodily to the stream valley below. Bluegrass will generally succeed the forest and make of the less steep declivities fairly good pasture-fields; but even so, trodden by the cattle, the bluegrass burns out in the summer, weeds cover the face of the ground, and the whole valley becomes a waste useless to men and unsightly in the extreme. Such lands are better for wood-lots than for any other conceivable use; and in Iowa today, such is the liberality of our laws, the burden of taxation on lands devoted to forest is so light as to make wood-raising by far the most profitable service to which our liilsides may be turned. Besides all this we have the great advantage of landscape beaty, adding attractiveness to the entire region and so putting actual added value on every farm. It is indisputable also that the bordering forests contribute to the conservation of water in the streams, and in some measure influence the local rainfall; so that on every account wisdom suggests that the steep billside bordering such a stream as the Boone, should be kept covered with groves of native species of trees. This matter is more fully discussed in our Forestr:y Notes further on.

\section{ECONOMIC PRODUCTS}

\section{Limestone}

There are no quarries in Wright county, but the several quarries already referred to at Webster City have afforded a great amount of rubble stone and for vears furnished material for foundation walls, etc. Of Jate these sources are less used. Imported rock and artificial blocks have supplanted the local product. Stone was quarried in days gone by at Bell's Mill and the 
bridge piers there are constructed of local stone. Limestone was at one time quarried on the old Snell farm, section 16, Webster township, Hamilton county, and at several points up and down the stream from the Bell Mill, but none of these quarries are now in use. Sandstone has also been quarried to some extent; chiefly in section 13 in Independence township, Hamilton county. The foundations of the new bank building at Kamrar are reported to have come from these quarries. This rock is certainly of very fair quality and might be taken out cheaply in large quantities.

Lime was at one time manufactured at various places along the Boone river, from Webster City south, almost at every point where lime-rock was quarried, but the kilns have to all appearance been long unused. The St. Louis limestones do not make the most satisfactory lime, and although convenient at one time for the service of the pioneer, its place is now supplied by the product of distant kilns.

\section{Sand and Gravel}

The allurial materials along the streams afford an abundance of sand and gravel, to say nothing of that obtained here and there from morainic hills and knobs. Gravel benches are not infrequent along the Iowa. There is a large pit used by the rai]ways about three miles north of Belmond. Sand and gravel are also obtained conveniently along the Boone river. At Webster City there is a large deposit of such material south of the eity. This is at present the basis of an extensive cement block industry. Sand is also found along the Skunk river near Randall; on Eagle creek east of Eag]e Grove is a bed of gravel used in road making. In fact this suggests the value of these deposits to all this part of the country; they furnish the very finest road material. The streets of all the towns have been covered more or less completely. with gravel and many a country road otherwise a marsh is mado passable by use of the same cheap material.

Artificial stone is extensively manufactured also at Belmond and at Dows. The building blocks of such construction, here as elsewhere, are likely to leave more and more unused the quarries 
of natural stone. Even the bowlders lie undisturbed in the field or at best are simply rolled unbroken from the pathway of the plow to find lodging in long, straight files by the barbed-wire fence along the highway.

\section{Fuel}

The pioneers in these counties built their cabins of logs along the principal streams, and timber for both building and fuel was abundant. To the present day wood is a common fuel although the forests have been wastefully and ruthlessly destroyed in every valley. The groves planted on the prairies, primarily for shelter, are now also a convenient source of cheap fuel and are largely so used. Wright county has no fuel, of local origin, except wood. Hamilton county is more fortunate. The western tier of townships in particular fall within the limits of the Ft. Dodge coal-field and the banks of the Boone river for miles in the lower course, nor less the banks of tributary creeks and ravines, show abundant natural exposures of seams of bituminous coal in veins of various thickness.

COAL.

Coal has been mined for years, but in irregular, desultory fashion, from a point some four miles directly south of Webster City at intervals all the way to the mouth of the Boone. Many of the "mines" are nothing more than an effort on the part of the landowner to procure where convenient with least trouble and stripping, a temporary supply of fuel. At other points drifting has been practiced and seams followed for considerable distances into the bank or hill. On the Brockshink farm a vein reported three feet.thick has been worked for many years. "Hundreds of tons of coal as good as any at Ft. Dodge," are said to have been taken here although at the date of visit, July, 1906, the mine seemed much, if not entirely, neglected. About one mile southeast of the Brockshink mines are the Silver properties. Here, beginning with exposures along the banks of a sharply eroded ravine, whose drainage is tributary to the Boone, a great amount of coal was at one time easily removed. The vein was probably the same as at Brockshink's, but there is no 
natural roof to protect extended mining, and at present slides cover almost all evidence of former activity. Along the river south of the mouth of Silvers creek, coal may be seen outcropping in several seams. The sliding bank on the west side affords an incomplete exposure. The section at this point has been previously given. The view of prospective mining is not encouraging at this point owing to the difficulty of either drifting or stripping.

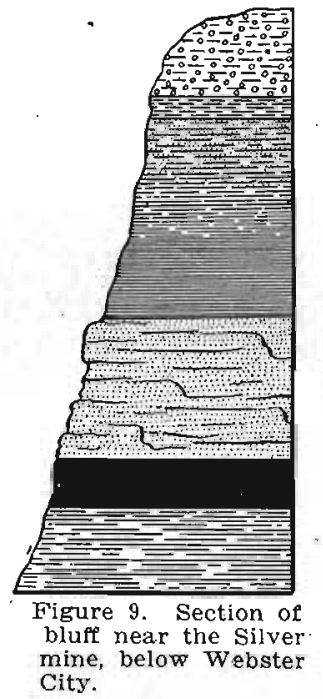

FEET. INCFES.

5. Shale $\ldots \ldots \ldots \ldots \ldots \ldots \ldots \ldots .6$

4. Shale, light and dark colored; somewhat sandy in places.. 448

3. Sandstone, massive, with occasional bands of bituminous shale $\ldots \ldots \ldots \ldots \ldots \ldots \ldots, 3 \quad 4$

2. Coal ................ 1

1. Shale, drab, and fire clay (exposed) $\ldots \ldots \ldots \ldots \ldots \ldots \ldots 2$

Across the river, east about thirty or forty rods, the stream, before the coming of the miner or of any creature who had use for coal, had already done a large amount of stripping and had left uncovered some acres of coal. This is in section 31 of Independence township. This stpply of coal was, of course, quickly exhausted. The seam probably represented No. 5, in section on page 124, already referred to. At any rate cannel coal has been taken out lower down in the natural exposure in the same field, and cannel coal outcrops on the west side of the river as shown in the section.

Further down the river are the Clatlin mines. These are worked more or less extensively during winter months and supply a local demand for fuel. Some of the drifts are timbered and veins two and one-half feet in thickness have been followed. The owner declined to give statistics so that probably the output is 
not large. Shafts at varying depths in the neighborhood reach good veins of coal, the depth depending in the main upon the surface topography: At the bend of the river in section 13, Webster township, drifting was at one time attempted on a large scale, but a great slide has obliterated almost every indication of human industry. Only here and there the entrance of a tunnel may be guessed by the topography or by the ruined frame-work still projecting and here and there masses of conein-cone along the river-bank indicate that the miner has been at work.

At Stockdale, about two miles west, in the southeast quarter of section 10, mining has been carried on for some forty years.

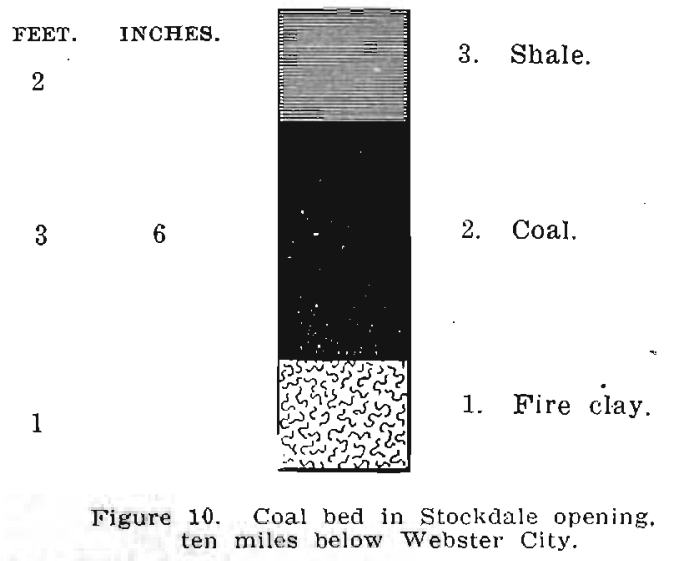

There are a number of timbered openings yet in evidence and quantities of shale and refuse cumber the ground, but at the time of examination all work seemed long suspended.

Report has it in all these cases that the cost of timbering the shaft or drift, and the insecurity of the roof in many places, makes the mining of coal in Hamilton less attractive. Coal there is in abundance and of fair quality; some of it as good as the best; but at present it is of less value. Certain it is also that the coal company railway from Webster City goes to Lehigh and not to Stockdale, which may or may not be significant.

It remains to be said that well-diggers report thin veins of coal as far east as section 2 in Clear Lake township, but in general the coal field in this neighborhood probably does not extend very far east of the Boone river nor much north of the 
middle of township 88 North. However erratic bits and pieces of coal are to be found in the drift even north of Webster City which indicates that outlying patches of the Iowa coal district may occur yet farther north. Our only source of information here will be the record of the drill.

\section{Brick and Tile Manufacturers}

Kilns for burning brick and tile are in operation at several places in these counties but generally the material used is in whole or in part a Carboniferous clay or shale brought from Lehigh in Webster county. Thus at Eagle Grove where 400$500 \mathrm{M}$. tile and 150-200 M. brick are manufactured per year, all the clay is imported. The clay comes from Lehigh, the coal from Des Moines. At Webster City is a much more extensive manufactory. Three or four million brick are produced per year and a large quantity of tile. The material used is Lehigh clay mixed with the output of a local pit, in proportion of about two to one. The local material appears to be a river silt and is found along the stream about half a mile east of the tile works.

At Jewell Junction local material is used, and the result is less satisfactory, pebbles affording much trouble. However, about $200 \mathrm{M}$. tile per year are manufactured and about $100 \mathrm{M}$. second-rate brick.

At Goldfield there is an unusual deposit of rather superior brick clay. This is near the river and appears to be alluvial in character. The exposure shows about as follows:

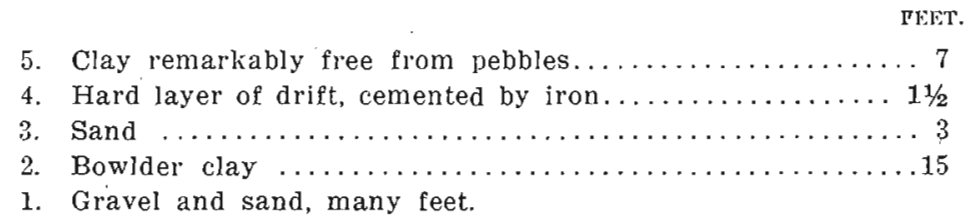

Number 2 is probably Kansan. Numbers 3 and 4 may represent also older drift, as Buchanan gravels. In any event the clay is alluvial and is serviceable, $125 \mathrm{M}$. brick are turned out annually and $500 \mathrm{M}$. tiles.

At Dows is another plant using a local deposit. The clay here lies beneath an alluvial deposit full of pebbles, and is itself prob- 
ably alluvial, since it contains much organic matter. It is very free from pebbles and the tile is of good quality. This factory is in Franklin county, just outside our present limits.

\section{Water Supplies}

Wright and Hamilton counties are well watered. The natural perennial streams already described are now supplemented in many places by long open ditches to be fed by miles of tiling. These will certainly remain living streams as if fed by springs, and although not without their inconveniences, such ditches will afford water for cattle for all the farms they pass.

The Boone river was at one time famous for mill-seats; and although at present there is found not a water-power in Hamilton county, there were at one time no less than five from the vicinity of Webster City south.

The tunnel mill in Webster township secured the needed fall by taking advantage of a long bend in the river where the current returns upon itself passing so near its upper course that a tunnel of a few rods length caught the stream at the higher level of a mile and a half above. The tunnel remains, but the mill has disappeared. Farther down stream is the ruin of the old Bell mill known to the earliest pioneer, but now forgotten of their children.

But the water supply of the two counties we describe is in large measure independent of the streams. Wells are universal and comparatively easy of construction. Good water is commonly obtained at moderate depth, from ten or fifteen to one hundred feet, generally from the sands and gravels under the drift. Some wells reach the St. Louis limestone and are deeper.

Flowing wells in these counties are by no means unusual. Indeed we seem here to be within the boundaries of an extended flowing well district which as we are coming to know it is sufficiently extended to merit careful investigation and study. Beginning at least as far north as Marshall, Minnesota, and extending in Iowa south and east in a strip, only a few miles in width, through Kossutll, Winnebag'o, Hancock, Wright, Hardin, Hamilton, Story, Marshall, Tama, Benton and Iowa counties, at least as far as Ladora, we have a region of flowing wells offering a 
geological fact of much interest and suggestiveness. This is not the place, nor are exact data at hand for a full discussion of this matter, but it may be stated in order to give a general view of the facts now before us that beginning at Marshall, Minnesota, and passing directly to Iowa there are flowing wells about and in Germania, near Titonka, thence south to Hutchins, and commonly in the western townships of Hancock county, about Renwick and Goldfield and Eagle Grove and Woolstock and Webster City, nor less about Swaledale (Cerro Gordo county), Belmond, Rowan, Popejoy, Alden, Buckeye; thence to Ellsworth and south to Story City, in the eastern townships of Boone county, about Ontario and Ames, east to Zearing, Marietta, Garwin, Gladstone, Belle Plaine and so on to Ladora and Victor. In a preceding volume (Present Series, Vol. IX, pp. 523-562) Mr. H. R. Mosnat discusses the Belle Plaine area and suggests the possibility of "a preglacial river valley now completely filled up and obliterated." Mr. Mosnat refer's to the Story City wells but thinks the two fields hardly continuous. The facts of distribution, however, as just cited, seem to indicate that they may be. The Wisconsin flowing well field is undoubtedly one and it approaches the Belle Plaine area within sixteen or eighteen miles. The flowing of a given well, of course, depends in part upon the local topography; and until we know more exactly the head of water in the drift wells over the entire area discussed we may not be certain whether we have a continuous aquifer, or source of supply, or not; possibly not even then.

The situation is however, suggestive. A map of the district sketched would indicate at least a continuous pre-Kansan deposit of gravel and sand extending from far up in Minnesota to the southern part of Iowa. This again would mean the pathway, of course, of an old time current. The direction of this current marks the drainage of the pre-Kansan landscape and it is interesting to note that the general trend was apparently then the same as at the present day.

It remains to be noted that the flowing wells in the counties before us are exceedingly useful, the water usually potable and fine. Nearly always the report is that the water comes from below the blue clay, sometimes from sand just on the rock, which

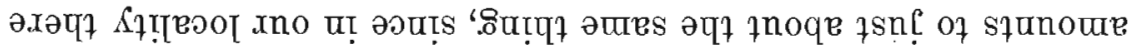


is in general not much of any other formation between the Kansan and the St. Louis limestone, the country rock. The city water at Webster City comes from fourteen flowing wells, one ten inches in diameter, the others, four. The head here is said to be about ten or twelve feet above the ordinary level of the river. This magnificent fountain comes from a gravel and sand layer on the rock about one hundred feet below. At the tile works in Eagle Grove the water of a flowing well rises in an inch pipe at present eighteen feet above the surface. Flowing water is reported in this well at different levels; that which supplies the present current is 125 feet below the surface. The flowing well at Goldfield is near the railway station and has delighted travelers for many a year.

\section{FORESTRY NOTES FOR WRIGHT AND HAMILTON COUNTIES}

White men seem to have entered Wright and Hamilton counties by way of the rivers. The migration, like that of birds in spring, was by way of the woods and thickets. The narrow valley of the Des Moines was filled with the densest kind of forest, not less the smaller but no less chasm-like valley of the Boone. While all the level ground above was marsh or prairie, these deep furrows were dark with trees among whicli wound in transparent clearness, amid the bowlders, not without music, the fairest perennial river's, confined by the vegetation to a restricted or but slowly changing channel. Among these trees and by these waters the pioneers built their cabins; cleared away a few acres where the alluvium was broadest and highest, and shaped their dwellings from the logs. They never dared occupy the bare fields above them. Storm swept in winter and fire swept in autumn or in spring - the prairies seemed impossible of occupation. Plate XVII.

It is curious to note that the fires which year by year mowed the vast plains seem seldom to have entered these deep and narrow valleys-probably in winter these received more than their quota of snow; old residents tell how the valley of the Boone seemed sometimes in its upper channel almost filled with driven snow. The snows in such case lingered longer here in 


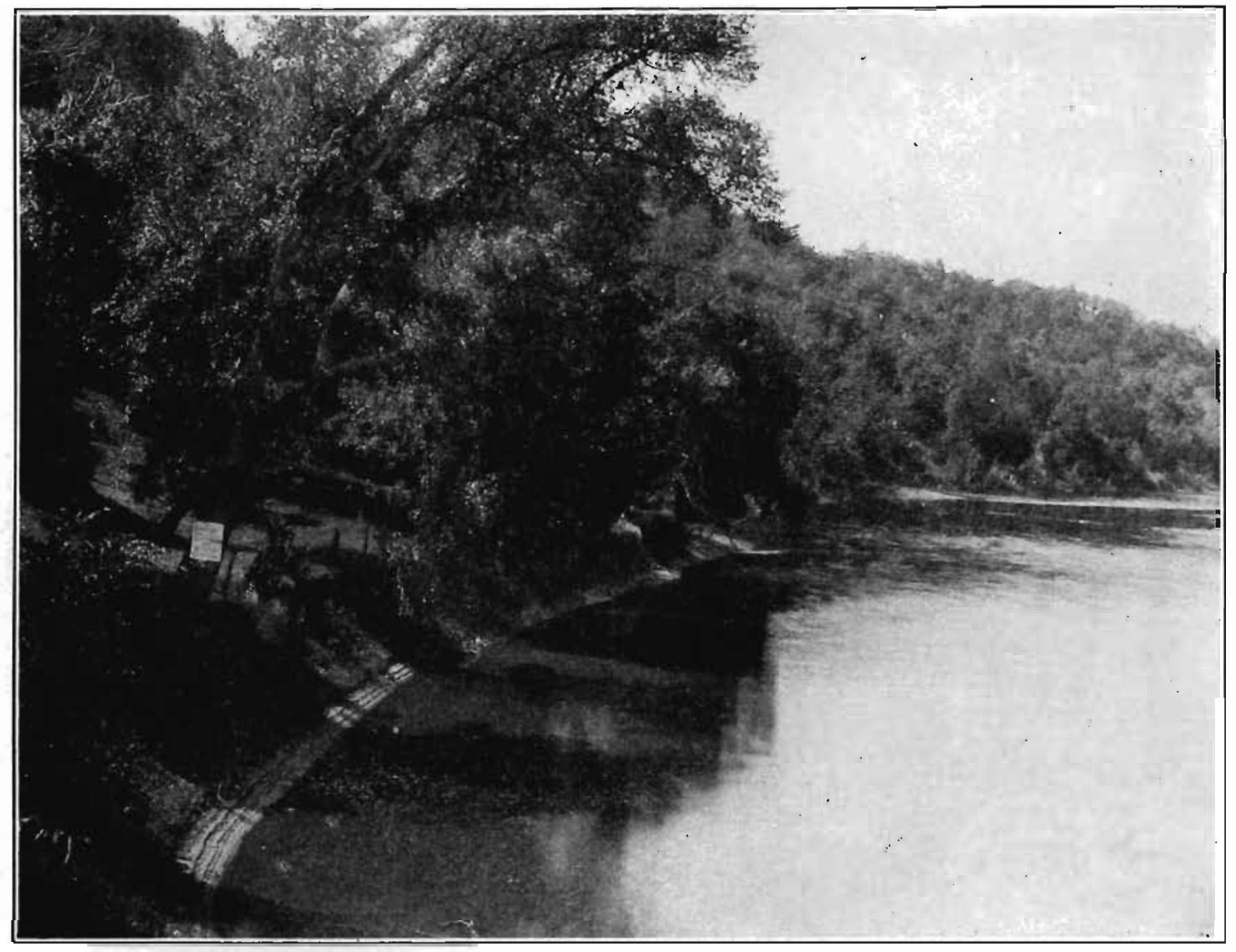
Plate XVII. The narrow valley of the Des Moines was flled with forest. The Des
Moines river, looking south from the bridge northeast. of Stratford. The 
spring and so defended from fire the vegetation of such protected strongholds. Did the fire sweep the prairies late after the frosts of autumn, still in these river canyons the vegetation remained longer green. Besides, the mists of the river perhaps dampened, at least a little, everything day by day quite up to the valley-rim.

Be all this as it may, it is still the testimony of those who know, and present conditions verify the story, that only along the streams did forests flourish. We say present conditions reveal this fact, for, although nearly all the original forest has been rigorously cut away, yet here and there in places less accessible, some of the old trees still stand and these are almost invariably within the trough-like valleys of the streams. Since by the coming of white men and particularly by the cultivation of the prairie, especially during the last forty or fifty years, the prairie fires have ceased, the forested area has been much extended. Young trees of all native species spread out over the margin of the valleys, occupied with thrifty groves the sharp ravines of secondary or tributary streams or even narrow drainage coulees and until within comparatively recent years, bade fair to show in these prairie counties a wealth of woodland greater than the past had seen. Within the last two decades, however, the great increase in the value of agricultural lands in Iowa, even of lands unfit for tillage but suitable as thought for pasturage, has made profitable, at least in seeming, the artificial use of every accessible acre. The axe has been applied to every wooded slope, as well as to the thickets of the more serviceable and convenient lowlands, and the forests disappear.

Now there is no question that there are some tracts of land, not generally extensive, once tree-covered, which now serve excellently for pasturage or tillage; nevertheless it will usually be found that lands in the prairie regions primarily forest are when denuded subject.to various disadvantages that diminish measurably the profit of their use. Such lands are either steep or close along the banks of streams. In either case they are sure to suffer from the erosive effect of storm water. If steep, the best soil speedily washes off, even if the whole surface does not cut into gullies or slide bodily an acre or two at a time. 
If by the river, high water is apt to change frequently the course and current of the streams and to leave instead of a fine meadow or forest simply a widening desert of rocks and gravel and sand, into which in summer the very river seems inclined to sink out of sight. All these results may be noticed in all parts of Iowa where from our stream banks, the primitive fringe of forest has been cut away.

It is true, such is the beneficence of nature, that in Iowa, the removal of the trees is usually followed by bluegrass affording feed for cattle; but even bluegrass does not hold the soil like trees. Bluegrass on the steep hillsides, closely grazed, does not even hold its own. There are hillsides in Iowa today so grown up with ragweed of an impoverished sort that even goats find their occupation gone.

On the other hand there are many and good reasons why our native woodlands along the Boone and Skunk should be preserved as such. In the first place, as intimated, this is the most convenient use for these lands so subject to erosion and wear. Trees will hold these lands and use them indefinitely. In. the second place, the tree cover protects the local water supply, by holding back too rapid drainage of the slopes. This at the same time prevents torrential streams, and floods that destroy the valleys and render vain and worthless all the toil of the farmer as his meadows and crops are swept away. But the trees themselves are of value. At present prices for lumber no farmer can any longer afford to be without his own woodlot. In days gone by when great forests of pine covered Minnesota and Wisconsin, this matter was of less concern, but today when lumbermen are prizing every stick from six inches up, when our two by four scantlings are made of mere saplings where only one piece of lumber is taken from a tree, it is evident that times have changed. Six-inch trees will grow in Iowa as quickly or more qnickly than anywhere else, and the time is near when we shall raise our own supply. of building material. Today portable sawmills are busy sawing into dimension stuff the very cottonwoods that our fathers planted but which have heretofore been thought worthless for lumber. 
Finally, it is cheaper to keep a woodlot than to raise one. Our native groves offer a great variety of self-renewing species; a little care gives to the farmer a perpetual supply of fuel and lumber.

This matter has seemed to our legislators of such importance that in Iowa forestry statutes practically exempt from tazation lands devoted to orchard, grove and wood. When this fact becomes generally known the wooded area of the state will doubtless rapidly increase.

The most important woody species in the Boone valley-and this is typical of all the wooded parts of Hamilton and Wright counties, where woods are confined to stream valleys or borders of lakes and ponds-are here listed. In preparing this list the author acknowledges the generous assistance of Mr. M. P. Somes, an authority on the flora of this part of Iowa.

1. Juniperus virginiana Linn. Red Cedar.

This seems to be the only evergreen native to this part of Iowa. It is a fine little tree, whether for ornamental or more practical purposes. It grows in the shade of other trees and hangs to the steep banks of the river below Webster City, especially as the Boone approaches the Des Moines. There are large trees still standing in Webster township and small specimens are abundant. Cedar makes a good hedge, a fine border to the windbreak, and cedar posts are among the very best. Good cedar posts are raised in twenty years from the seed; from nursery plants in much less time, for the tree grows rapidly under favorable circumstances.

While this is the only native evergreen it must be understood that all other common species flourish here when planted. Larch, white pine, sprum, do well and may be made to contribute to the farmer's service.

2. Populus deltoidea Marshall. Cottonwood.

This is the old friend of the pioneer, planted everywhere by the bolder men who left the native grove and essayed the prairie. The seeds of the cottonwood are carried for miles on the winds of early summer and germinate immediately they find lodgment and moisture. Consequently they are apt to spring up at the borders of lakes and sloughs, on the sandy bars and banks of 
rivers, where they come up from year to year in uncounted thousands. On the open prairies the fires generally kept the seedlings down, but occasionally a lone tree grew old and stormtossed, a landmark for travelers.

As already suggested, cottonwood makes good dimension-lumber, since men have learned how to pile and dry it. "Tortuous and errant in its course of growth" the boards, if tossed out carelessly from the saw, twist to worthlessness; but when carefully bandled there seems no reason why cottonwood may not for many important purposes take the place of pine.

Cottonwoods are not social trees, are efficient only at the margin of our plantings, some other species must be used to fill up the interior.

3. Populus grandidentata Mx. 'Aspen.

The aspen or upland quaking asp, is one of the quick growing trees of our native woods. It springs up quickly and reaches early maturity. The trees generally occupy a definite place on a hillside, form fine straight poles, forty or fifty feet in length, but presently die or are supplanted by trees of other species. A very different tree from the ordinary quaking asp-next named species. Useful as affording poles of service to the farm and making excellent though light and quick-burning fuel.

4. Populus tremuloides Michx. Quaking Asp.

The quaking asp is a small tree found commonly in the border of native woods and groves. Often it occurs about an open area in the middle of a forest, especially where such opening is occasioned by a marsh or is an undrained natural meadow. In such cases the little stocky trees, their myriad dark green diminutive leaves all aquiver form a familiar and pleasing border to the somber wood behind. Except as an ornamental plant the tree has little value.

5. Salix discolor Muhlenberg. S. amygduloides And. S. nigra Muhl. Willow.

These are the principal species of willow in our region. The first is the common species about prairie streams and marshes. Its leaves, bright green above and silvery below, make this a handsome ornamental shrub. The other two species named are the willow trees native to the river valleys, sometimes forty or 
fifty feet high. They love the water and grow close to it. Useful chiefly for fuel and posts.

6. Juglans nigra L. and Juglans cinerea L.

These are the common Walnut and Butternut respectively. Of the black walnut the early settlers report large specimens in the valley of the Boone, and plenty of young trees a foot or more in diameter are still to be found in favored situations. Than the black walnut there is no finer tree. The old trees are nearly all gone, split into rails, sawed into lumber, cut for cord wood. But fortunately the tree springs readily from the seed and grows rapidly to utility and value. It is essentially a forest-tree, loves low rich sandy soils; but grows on the rich prairie soil very well too. It is however, very exclusive. No farmer can raise walnut trees and cattle on the same ground. The experiment is in process near Stratford with results sad to behold.

7. Hicoria minima (Marsh) Britt.

Hicoria ovata (Mill.) Britt. Hickory.

The hickories, so far as observed, are represented here by two species only. The first, the pig-nut or bitter-nut, has small thinshelled and thin-husked fruit, inedible, except by the pigs, and possibly the squirrels. The second is the familiar hickory-nut tree. Both trees are valuable for fuel; the second affords a particularly strong and serviceable timber, now becoming scarce and costly. It is needless to tell a farmer the value of hickory poles for wagon stock. This tree is certainly worthy of protection if not cultivation.

8. Carpinus caroliniana Walt.

Ostrya virginiana (Mill.) Willd.

Corylus americana Walt.

These three small trees or bushes, form an interesting group of related forms, all worthy of preservation. The first is more often called blue beech or water beech. It is not a beech at all, rather an iron-wood; but it has beech-like bark and a small, somewhat three cornered seed, and these peculiarities possibly suggested the name. The tree, for small tree with us it is, grows close to the water, often right at the water's edge, by all 
our northern streams, usually in thickets. The wood is exceedingly dense and strong and makes the best of tool handles, small repair stock, etc.

The second species named; the iron-wood, is a more common tree on all the hillsides; grows larger with us and is esteemed for fuel. The wood is also very hard and strong and is useful for several purposes, same as the last.

The third species is the familiar hazel nut. It is a border shrub, usually marks the transition to the fertile prairie, although by no means eschewing fertile soils itself. The nuts are the delight of healthy children and the plant should be preserved if for their enjoyment only.

9. Quercus alba L.

Quercus macrocarpa $\mathrm{Mx}$.

Quercus rubra

Quercus schneckii

Quercus coccinea. The oaks.

This familiar group represents one of our finest series of trees, invaluable for every purpose for which wood can be used. The two species first named are the white oaks; the last three black oaks. Of the white oaks the first is the white oak proper, invaluable and eminently worthy the attention of every land owner; the second is the burr oak, so called on account of its rough cupped acorns. The burr oak is not quite so fine grained as is the white oak proper, but its wood when the tree is at its prime is exceedingly strong and fine. There are still standing many of the original native burr oak trees about the streets of Webster City, contributing much to the beauty of that town.

Of the black oaks less may be said; still $Q$. rubra, the red oak, furnishes a favorite lumber, beautiful for indoor finish. The black-oak group is notable for its pointed leaves, each lobe ending in a spine or bristle. The red oak has large cylindric acorns, the other two are with difficulty distinguished except by the careful observer; they commonly pass by the general name of jack oak.

10. Ulmus americana $\mathrm{L}$.

Ulmus fulva $\mathrm{Mx}$.

Celtis occidentalis $\mathrm{L}$. 
'This is the elm group as represented in all western Iowa. The first is the common white, or American elm, of the trees of our lowlands, none finer. Perhaps also the most complaisant species we have, growing wherever and almost however planted, if right end up. No tree so commonly transplanted, no tree so generally abused in process. Very variable in habit is the white elm. Some trees are erect and regular, others low and spreading, some straight and symmetrical, others persistently crooked. This fact must be taken into account where one desires ornamental effect in planting. Elm wood is good for all purposes, and the old trees are rapidly passing into lumber throughout the whole country. The second species, the red or slippery elm, has much less economic value. Celtis is the hackberry, a beautiful forest tree, making fine fuel, and exceptionally handsome as an ornamental tree.

11. Malus iowensis (Wood) Britt.

Amelanchier canadensis (L.) Medic.

Crataegus crus-galli L.

Crataegus mollis (T. \& G.) Scheele.

Crab apples and hawthorns are everywhere where Iowa supports forests at all. Our crab apple, in the opinion of botanists, is all our own and carries the name of the State to scientific fame. The second species listed is the June-berry or service-berry, beautiful in bloom in the very early spring when flowering shrubs are rare. The last two species are hawthorns; the first is distinguished by remarkable spines, long and slender; the latter by soft leaves, especially when young, and large red edible fruit.

All these are ornamental trees chiefly. They make an interesting border to our plantings, or stand in scattered clumps, beautiful at all seasons. The hawthorns can even withstand pretty well abuse by cattle and persist in the parched, hard-trodden pasture field.

12. Prunus americana Marsh.

Prunus serotina.

The wild plum and wild cherry form an interesting part of our forest flora. With us the wild cherry is seldom large enough for lumber, but eastward it attains great dimensions and makes fine cabinet material. The wild plum, the first species here 
named, has been deservedly popular for its delicious fruit. Birds scatter the wild cherry everywhere, while the wild plum has been often transplanted and is in some of its varieties the basis of our common garden fruit.

13. Robinia pseudacacia L.

Gleditschia triacanthos L.

Gymnocladus dioica (L.) Koch.

These are the pod-bearing trees of our Iowa woods and groves. Robinia is the common black locust, probably introduced, but now growing as if native everywhere; Gleditschia is the honey locust, a familiar and beautiful forest tree; and the third species receives in popular phrase the somewhat protracted title coffeebean-tree. All are beautiful trees. The first two furnish wood of extreme value; nothing better for posts. The coffee-beantree makes good wood, but is withal an extremely handsome species, and even attractive in winter when, all its leaves discarded, its twigless branches seem as if stripped for storm.

14. Acer saccharinum L.

Acer nigrum $\mathrm{Mx}$.

Acer negundo L.

The maples and willows are par excellence the Iowa farmer's trees. These have been universally planted. Especially is this true of the first species and the last in the list here cited. The soft or silver maple and the box-elder are our most commonly known trees. Acer nigrum is the present scientific or rather botanical name of the hard or sugar maple. This tree has its value every way and everywhere, but the soft maple and boxelder grow so rapidly and easily in all sorts of places that their utility as the basis of grove or windbreak on the inhospitable prairie is a matter of fifty years experience. It is time, however, that other trees affording better wood should come into general use. At least with such a variety as is here listed to select from, native to the region, there is no reason why our farms should not exhibit a far more pleasing diversity.

Near the mouth of the Boone river and especially along the Des Moines where it approaches our territory occurs a curious little buckeye, Aesculus octandra Marsh. This is another native species which deserves an introduction to our lawns and forest 


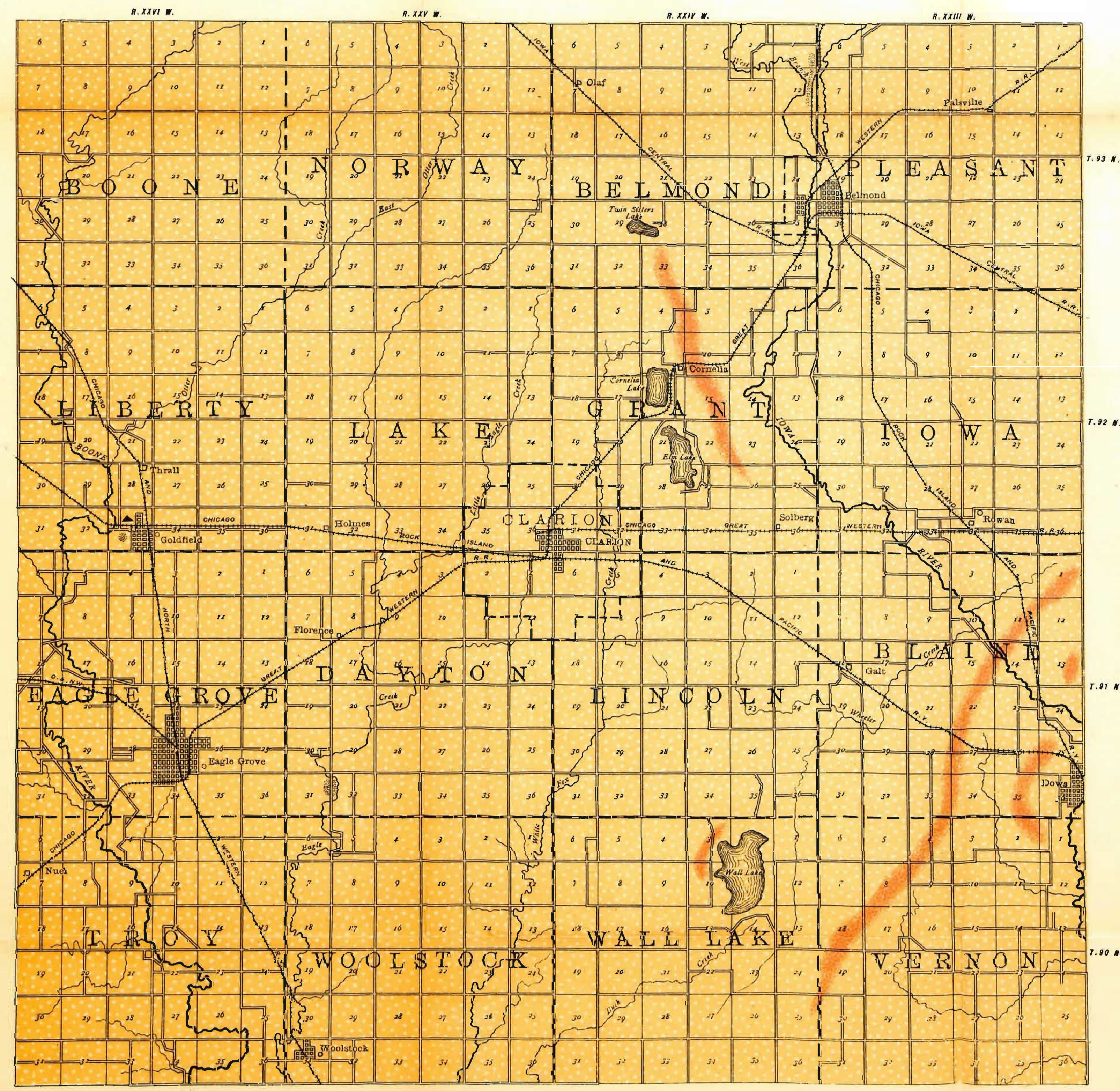

IOWA GEOLOGICAL SURVEY

MAP OF THE

SURFACE DEPOS/TS

WRTE[T

COUNTY.

IOWA.

BY

T. II. MACBRIDE

1910

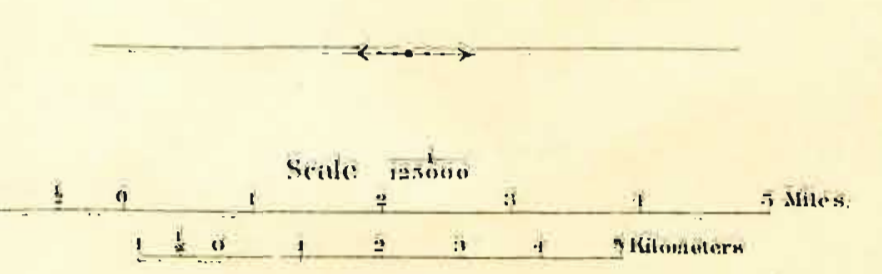

L. EGE N D GEOLOGICAL FORMATIONS

$$
\text { WISCONSIN DRIFT }
$$

WISCONSIN MORAINE

INDUSTRIES
WORKS
ING PITS.


plantings, chiefly for its beauty. It is a small tree, as already noted, but its rich glossy foliage, curious flowers and fruits make it well worth our interest and attention. Unless cared for it is likely to disappear entirely.

15. Tilia americana. Basswood; Linden.

This beautiful species is well known and well appreciated. It is not so widely planted as it deserves. The soft wood is serviceable for lumber; but the chief value of the tree is for ornament and shade. The apiarist also puts in a claim on the source of pasture for his bees. Basswood honey is for most judges the very best.

16. Fraxinus lanceolata Borck.

Fraxinus nigra Marsh.

The ash is valuable for its wood. It makes excellent fuel, but more, its wood enters largely into the construction of machinery. The first species mentioned is the better and is that now widely planted. The ash grows more slowly than maples at the outset, but once started makes a good growth and is a clean, durable, in every way satisfactory contribution to our arboriculture.

In addition to these arboreal forms of vegetation, Hamilton and Wright counties possess as natives all the minor species of woody plants characteristic of north-central Iowa. We have snowberries and honeysuckles, sheepberry and elderberry, at least three species of dogwood or cornel; we have the wild grape and Virginia creeper, Jersey tea and wild indigo, burning bush and bittersweet; we even have plenty of poison ivy; then there are sumac, wild gooseberry and wild currants two or three species, one already in cultivation because of its beauty (Ribes missouriensis); we have wild roses, blackberries, raspberriesin fact all the small things that go to fill up the chinks and make up a woodland landscape. Everything needed to make beautiful the most unsightly corner of any farm or holding is already all ready for use. It remains only for human intelligence to supplement natural resources to make this part of Iowa a worthy portion of what is yet to be the most beautiful agricultural garden of the world. 
